OPEN ACCESS

Edited by:

Yun Chen,

Zhejiang University, China

Reviewed by:

Natacha Bodenhausen,

Research Institute of Organic

Agriculture, Switzerland

Guo-chun Ding,

China Agricultural University, China

*Correspondence:

Miao Wang

m.wang@rug.nl

Specialty section:

This article was submitted to Plant Microbe Interactions,

a section of the journal

Frontiers in Microbiology

Received: 20 June 2017 Accepted: 13 October 2017 Published: 30 October 2017

Citation:

Wang M, Li E, Liu C, Jousset A and

Salles JF (2017) Functionality of Root-Associated Bacteria along a Salt Marsh Primary Succession.

Front. Microbiol. 8:2102.

doi: 10.3389/fmicb.2017.02102

\section{Functionality of Root-Associated Bacteria along a Salt Marsh Primary Succession}

\author{
Miao Wang ${ }^{1 *}$, Erqin $\mathrm{Li}^{2}$, Chen Liu ${ }^{2}$, Alexandre Jousset ${ }^{3}$ and Joana F. Salles ${ }^{1}$ \\ ${ }^{1}$ Research Group of Microbial Community Ecology, Genomics Research in Ecology and Evolution in Nature, Groningen \\ Institute for Evolutionary Life Sciences, University of Groningen, Groningen, Netherlands, ${ }^{2}$ Plant-Microbe Interactions, \\ Department of Biology, Utrecht University, Utrecht, Netherlands, ${ }^{3}$ Ecology and Biodiversity, Utrecht University, Utrecht, \\ Netherlands
}

Plant-associated bacteria are known for their high functional trait diversity, from which many are likely to play a role in primary and secondary succession, facilitating plant establishment in suboptimal soils conditions. Here we used an undisturbed salt marsh chronosequence that represents over 100 years of soil development to assess how the functional traits of plant associated bacteria respond to soil type, plant species and plant compartment. We isolated and characterized 808 bacterial colonies from the rhizosphere soil and root endosphere of two salt marsh plants, Limonium vulgare and Artemisia maritima, along the chronosequence. From these, a set of 59 strains (with unique BOX-PCR patterns, 16S rRNA sequence and unique to one of the treatments) were further screened for their plant growth promoting traits (siderophore production, IAA production, exoprotease production and biofilm formation), traits associated with bacterial fitness (antibiotic and abiotic stress resistance $-\mathrm{pH}$, osmotic and oxidative stress, and salinity) and metabolic potential. An overall view of functional diversity (multivariate analysis) indicated that the distributional pattern of bacterial functional traits was driven by soil type. Samples from the late succession (Stage 105 year) showed the most restricted distribution, harboring strains with relatively low functionalities, whereas the isolates from intermediate stage (35 year) showed a broad functional profiles. However, strains with high trait performance were largely from stage 65 year. Grouping the traits according to category revealed that the functionality of plant endophytes did not vary along the succession, thus being driven by plant rather than soil type. In opposition, the functionality of rhizosphere isolates responded strongly to variations in soil type as observed for antibiotic resistance $(P=0.014)$. Specifically, certain Pseudomonas sp. and Serratia sp. strains revealed high resistance against abiotic stress and antibiotics and produce more siderophores, confirming the high plant-growth promoting activity of these two genera. Overall, this study contributes to a better understanding of the functional diversity and adaptation of the microbiome at typical salt marsh plant species across soil types. Specifically, soil type was influential only in the rhizosphere but not on the endosphere, indicating a strong plant-driven effect on the functionality of endophytes.

Keywords: functionality, plant-associated bacteria, plant selective force, soil type, salt marsh chronosequence 


\section{INTRODUCTION}

Plant-microbial interactions influence ecosystem functioning through carbon sequestration and nutrient cycling - in natural ecosystems as well as in agricultural systems (Singh et al., 2004; Hussain et al., 2011; Ribeiro and Cardoso, 2012; Hong et al., 2013; Shakya et al., 2013) - thus understanding the drivers of the plant associated microbiome is of great relevance (Berg and Smalla, 2009). Factors such as soil properties and plant species are known to influence the structure and function of microbial communities living in close association with plants, in particular those known as plant growth-promoting rhizobacteria (PGPR; Garbeva et al., 2004a; Jousset et al., 2006; Rasche et al., 2006; Berg and Smalla, 2009). The relative importance of the latter is due to species-specific root exudation patterns, which leads to the enrichment of plant-specific microbial populations in the rhizosphere - the rhizosphere effect (Rovira, 1956; Uren, 2000). For instance, field experiments have shown the influence of plant species on the structure and function of bacterial communities associated with the rhizosphere of three phylogenetically different and economically important crops - strawberry, potato and oilseed rape (Smalla et al., 2001; Berg et al., 2002, 2006; Costa et al., 2006).

The rhizosphere effect varies, however, at different sites because of differences in microbial biogeographical patterns, soil properties and land use (Marschner et al., 2001; Garbeva et al., 2004b; Salles et al., 2006; Lauber et al., 2008), making impossible to disentangle the effects driven by soil type from those related to plant species. By analyzing the phylogenetic distribution of soil bacterial communities along a natural gradient of soils under the influence of the same meta-community and environmental variation, we have recently shown that soil type exerts greater effect on rhizosphere communities than plant, as indicated by the fact that the rhizosphere microbiome followed the changes observed in the bulk soil. However, the endophytic bacterial communities - i.e., those capable of gaining access to the internal root endosphere compartment (Sessitsch et al., 2002; Compant et al., 2005, 2010; Hardoim et al., 2008; Lundberg et al., 2012; Saleem et al., 2015) - were driven by the plant, clustering away from rhizosphere and bulk soil samples and irrespective of soil developmental patterns (Wang et al., 2016). Thus, the intimate relationship between endophytes and plants generated stronger plant selectivity on the phylogenetic distribution of bacterial communities when compared to rhizosphere samples (Hallmann et al., 1997; Rosenblueth and Martínez-Romero, 2006; Schulz and Boyle, 2006).

The phylogenetic information is, however, not always linked to the functionality of the communities (Salles et al., 2012; de Bello et al., 2015) and given the high microbial functional redundancy (Nannipieri et al., 2003; Mendes et al., 2015; Sunagawa et al., 2015), it remains unclear whether similar patterns will arise when functions rather than identity are targeted. The plant microbiome is known to be enriched in functional traits related to root colonization (e.g., transporters), metabolic pathways (e.g., polysaccharide degradation, hydrogen metabolism) and plant growth promoting (PGP) phenotypes (Ofek-Lalzar et al., 2014; Yan et al., 2016). Interestingly, microbial functionality seems dependent on the plant compartment (rhizosphere or endosphere), as shown for phylogenetic information, given that the endosphere microbiome might harbor significantly more metabolic pathways (degradation of multiple aromatic plant metabolites) and PGP phenotypes (production of IAA) than those microbes colonizing the rhizosphere (Timm et al., 2015). It remains unclear however, how soil properties would influence this selection and whether microbial functionality is mostly driven by plant-specific selection or by the soil parameters.

In this study, we aim at exploring the importance of the selective force exerted by the plant in regulating the functionality of plant-associated bacterial species, in different soil types along a salt marsh primary succession chronosequence (Olff et al., 1997; Dini-Andreote et al., 2014, 2015; Wang et al., 2016). We chose Limonium vulgare and Artemisia maritima, typical perennial salt marsh plants, as our focus species because of their broad distribution along the chronosequence, allowing for a full comparison between plant species, plant compartments and soil types. The bacterial functionality was determined by measuring traits associated with bacterial fitness (antibiotic and abiotic stress resistance - $\mathrm{pH}$, osmotic and oxidative stress, and salinity), metabolic potential determined by growth on different carbon sources, and PGP capacity (siderophore production, IAA production, exoprotease production and biofilm formation). Functionality was assessed by targeting all traits simultaneously (overall functional diversity), specific groups of or individual traits. We hypothesize that the functional diversity of the rhizosphere isolates but not those from root endosphere will increase along succession. Specifically, we expect the functionality of rhizosphere bacterial isolates to change along the soil succession, thus following the increase in the complexity of soil nutrients, organic matter, plant diversity and biomass observed in this system. Conversely, we expect the functionality of those isolates associated with root endosphere to, remain constant, given the plant selectivity and buffering effect previously shown for this system (Dini-Andreote et al., 2014, 2015; Wang et al., 2016).

\section{MATERIALS AND METHODS}

\section{Study Site and Sample Collection}

Sampling was performed in April in the year 2016. Plant samples were collected at five distinct successional stages in the salt marsh chronosequence. This chronosequence spans more than 100 years of primary succession and is located on the island of Schiermonnikoog $\left(53^{\circ} 30^{\prime} \mathrm{N}, 6^{\circ} 10^{\prime} \mathrm{E}\right)$, Netherlands (for detailed information on sampling, see Wang et al., 2016). Samples were collected at locations with successional ages of $5,15,35,65$, and 105 years. In this study, we use soil stage as a proxy of soil type, as previous work has revealed that the sedimentation caused by the tidal regime has resulted in modifications on the soil physicochemical conditions along the primary succession, leading to an accumulation of silt and clay particles. In addition, the salinity level also increased over time during succession, due to an accumulative effect. For the details on the establishment of sampling plots and descriptions on the chronosequence 
verification, see Olff et al. (1997), Dini-Andreote et al. (2014), and Wang et al. (2016). Briefly, triplicated plots within each of the locations were established at the same base of elevation [vertical position relative to mean sea level at the initial elevation gradient on the bare sand flats with a base elevation of $1.16 \mathrm{~m} \pm 2.2 \mathrm{~cm}$ (mean \pm SE) above Dutch Ordinance Level]. Within each plot, four healthy-looking L. vulgare and A. maritima of similar sizes with attached soil adhering to the intact roots were collected and processed together generating two composite samples per plot. Thirty composite samples in total were collected $(5$ stages $\times 3$ plots per stage $\times 2$ plant species). Each sample was placed into a sterile plastic bag, sealed and transported to the laboratory in $<24$ h. From each composite sample, we separated rhizosphere soil from plant roots (see below).

\section{Pre-treatment of Rhizosphere Soil and Plant Root Samples}

A detailed description for the workflow of the isolation and screening of plant-associated bacteria is given in Supplementary Figure S1A. Rhizosphere soil samples were collected by weighting ten grams of roots with tightly adhering soil particles (about 3 g rhizosphere soil). Root samples were transferred into an Erlenmeyer flask containing $47 \mathrm{~mL}$ of sterile 1X Phosphate Buffered Saline (PBS buffer) and shaken for $30 \mathrm{~min}$ at $200 \mathrm{rpm}$ at room temperature. An aliquot of $1 \mathrm{~mL}$ of the suspension with rhizosphere soil was transferred into sterile 1X PBS buffer and serial dilutions $(1 / 10)$ were prepared.

Plant roots (about $8 \mathrm{~g}$ ) were thoroughly washed with running tap water, trimmed to remove adhering soil and dead tissues, followed by surface sterilization, which consisted of immersion in $1.5 \% \mathrm{NaClO}$ solution for $3 \mathrm{~min}$, followed by $70 \%$ ethanol for $3 \mathrm{~min}$ and sterile distilled water $(3 \times 3 \mathrm{~min})$. The surfacesterilized root samples (5 g) were diced with a sterile scalpel and immersed into $45 \mathrm{~mL}$ of $0.9 \% \mathrm{NaCl}$ solution. After shaking incubation for $1 \mathrm{~h}$ at $28^{\circ} \mathrm{C}$, the suspension with root pieces was shaken using a horizontal vortex instrument $(4 \times 1 \mathrm{~min}, 30 \mathrm{~s}$ in-between). An aliquot of $1 \mathrm{~mL}$ of the suspension containing the released plant endophytes was transferred into sterile 1X PBS buffer and serial dilutions (1/10) were prepared. Sterility checks were performed by tissue-blotting surface-sterilized root samples on $\mathrm{R} 2 \mathrm{~A}$ plates at $28^{\circ} \mathrm{C}$ for $2-7$ days. Only samples without bacterial growth were considered successfully sterilized and used further.

\section{Bacterial Isolation and Identification from Rhizosphere Soil and Plant Root Samples}

R2A medium, as a non-selective medium recommended for the examination of total heterotrophic bacteria in soil (Ellis et al., 2003), was used to culture the heterotrophic population. Aliquots of $0.1 \mathrm{~mL}$ of the $10^{-1}$ to $10^{-3}$ dilutions from rhizosphere soil and root samples were spread on R2A medium plates and incubated for 2 days at $25^{\circ} \mathrm{C}$, after which we determined the number of colony forming units (CFU). A maximum of 32 bacterial colonies with unique morphologies per replicate were purified using a streak-plate procedure (see Supplementary
Table S1 for total numbers), transferred onto new R2A medium plates and further used as templates for BOX-PCR - a DNAbased typing method that differentiate bacterial species at strain level by simultaneously screening DNA regions scattered in the bacterial genome (Brusetti et al., 2008). To improve cell lysis, the colonies were first inoculated into $50 \mu \mathrm{L}$ of $\mathrm{NaOH}$ solution $(0.05 \mathrm{M})$ and then lysed at $95^{\circ} \mathrm{C}$ for $15 \mathrm{~min}$ in the PCR machine. BOX-PCR was performed by using the BOX-A1R primer (5'-CTACGGCAAGGCGACGCTGACG-3') (Versalovic et al., 1994). Twenty $\mu \mathrm{L}$ PCR reactions were performed using $0.32 \mu \mathrm{L} 5 \mathrm{U}_{\mu \mathrm{L}}^{-1}$ Taq DNA Polymerase, $4 \mu \mathrm{L}$ of $5 \mathrm{X}$ Gitschier Buffer [ $83 \mathrm{mM}\left(\mathrm{NH}_{4}\right)_{2} \mathrm{SO}_{4}, 335 \mathrm{mM}$ Tris- $\mathrm{HCl}(\mathrm{pH} 8.8), 32.5 \mathrm{mM}$ $\mathrm{MgCl}_{2}, 325 \mathrm{mM}$ EDTA (pH 8.8), 1\% commercial stock of $\beta$-mercaptoethanol, ddH2O], $2 \mu \mathrm{L}$ 100\% DMSO, $1 \mu \mathrm{L} 25 \mathrm{mM}$ of each dNTP in a mixture, $0.32 \mu \mathrm{L} 20 \mathrm{mg} \mathrm{mL}^{-1}$ bovine serum albumin (BSA) (Roche Diagnostics GmbH, Mannheim, Germany), and $0.8 \mu \mathrm{L}$ of $10 \mu \mathrm{M}$ BOX-A1R primer and $1 \mu \mathrm{L}$ of the lysed cell solution. The thermal cycler protocol was $95^{\circ} \mathrm{C}$ for $3 \mathrm{~min}, 35 \mathrm{cycles}$ of $94^{\circ} \mathrm{C}$ for $4 \mathrm{~s}, 92^{\circ} \mathrm{C}$ for $30 \mathrm{~s}, 50^{\circ} \mathrm{C}$ for $60 \mathrm{~s}, 65^{\circ} \mathrm{C}$ for $8 \mathrm{~min}$ and a final $16 \mathrm{~min}$ extension at $65^{\circ} \mathrm{C}$. BOX-PCR profiles were visualized by separation on $2 \%$ agarose gel and staining with ethidium bromide. Images of the gels were visualized and documented under UV light with Image Master VDS system (Amersham Biosciences, United Kingdom). For the details of the bacterial isolates showing unique BOX-PCR profiles, see Supplementary Tables S1 and S2. Culture stocks for individual isolate were stored in $25 \%$ glycerol at $-80^{\circ} \mathrm{C}$.

\section{Molecular Characterization of Bacterial Isolates}

A total of 159 bacterial cultures with unique BOX-PCR patterns (Supplementary Figure S1 and Table S2) were subjected to total DNA extraction using the MoBio UltraClean Microbial DNA Isolation Kit (MoBio Laboratories, Carlsbad, CA, United States). We followed the instruction manual, except for heating the preparations at $65^{\circ} \mathrm{C}$ for $10 \mathrm{~min}$ with occasional bump vortexing for a few seconds every 2-3 min. The amount of DNA in each sample was quantified using a NanoDrop ND-1000 spectrophotometer (NanoDrop Technologies). All DNA samples were standardized to the equal concentration of $5 \mathrm{ng} \mu \mathrm{L}^{-1}$ for further analyses.

$16 \mathrm{~S}$ rRNA gene amplification was performed by using the bacterial-specific primers, B8F (5'-AG AGTTTGATCMTGGCTCAG-3') (Edwards et al., 1989) and U1406R (5'-ACGGGCGGTGTGTRC-3') (Lane, 1991). Fifty $\mu \mathrm{L}$ PCR reactions were performed with $0.2 \mu \mathrm{L} 5 \mathrm{U} \mu \mathrm{L}^{-1}$ FastStart High Fidelity (FSHF) Taq DNA Polymerase, $5 \mu \mathrm{L}$ 10X FSHF Reaction buffer without $\mathrm{MgCl}_{2}, 0.8 \mu \mathrm{L} 50 \mathrm{mM} \mathrm{MgCl}_{2}$ stock solution, $1 \mu \mathrm{L} 10 \mathrm{mM}$ PCR nucleotide mix, $0.5 \mu \mathrm{L} 20 \mathrm{mg}$ $\mathrm{mL}^{-1}$ BSA (Roche Diagnostics GmbH, Mannheim, Germany), and $1 \mu \mathrm{L}$ each of $10 \mu \mathrm{M}$ primer and $5 \mathrm{ng}$ DNA template. The thermal cycler protocol was $95^{\circ} \mathrm{C}$ for $5 \mathrm{~min}, 35$ cycles of $95^{\circ} \mathrm{C}$ for $60 \mathrm{~s}, 52^{\circ} \mathrm{C}$ for $30 \mathrm{~s}, 72^{\circ} \mathrm{C}$ for $2 \mathrm{~min}$ and a final $7 \mathrm{~min}$ extension at $72^{\circ} \mathrm{C}$. Amplicons were run with $1 \%(\mathrm{w} / \mathrm{v})$ agarose gel to check the band size, and then sequenced at LGC Genomics GmbH (Berlin, Germany) on an Applied Biosystems ${ }^{\circledR}$ 3730XL DNA analyzer. 
The 16S rRNA gene sequences of bacterial isolates were compared with the reference sequences available in the Nucleotide Database of the National Center for Biotechnology Information (NCBI) using the basic local alignment search tool (Nucleotide BLAST) ${ }^{1}$. The accession numbers of the 68 unique strains identified at species level by the 16S rRNA gene sequences are MF664115 to MF664179 and MF677865 to MF677867 (Supplementary Table S3). Phylogenetic and molecular evolutionary analyses with the 16S rRNA gene sequences of bacterial isolates were conducted by using software MEGA 7.0 for bigger datasets (Kumar et al., 2016). The sequences were aligned by using the CLUSTALW (Thompson et al., 1997). Tree constructions were performed using the Maximum Likelihood [ML] method (Cavalli-Sforza and Edwards, 1967; Felsenstein, 1981, 1993). The robustness of the phylogenetic tree was confirmed by using 1000 bootstrap replications. Additionally, Chlorella vulgaris C-27 and Planctomycetes bacterium AS92 were included as the outgroup, and the validation of the phylogenetic neighbors was carried out by adding the 16S rRNA sequences of type strains obtained from the SILVA rRNA database project (Quast et al., 2013; Yilmaz et al., 2014). Phylogenetic tree was visualized and exported using the web-based tool Interactive Tree Of Life (iTol) (Letunic and Bork, 2011).

\section{Biochemical Assays for Functional Traits by Using Microtiter Plate Plant Growth Promoting Traits}

A detailed description of the functional traits screening for the plant-associated bacteria is given in Supplementary Figure S1B. For screening the PGP traits, bacterial culture supernatant was first collected. That was achieved by growing the individual isolates in 96-well microtiter plates containing Luria-Bertani (LB) medium. Plates were incubated at $25^{\circ} \mathrm{C}$ for 2 days, when cells reached the stationary phase (as determined by measuring absorbance at $600 \mathrm{~nm}$ ). Plates were then centrifuged $(2800 \mathrm{rpm}$ for $30 \mathrm{~min}$ ) and the supernatant was filtered through a 96-well microtiter filter plate. For each microtiter plate, negative controls were included by adding LB medium without bacterial culture together with other reagents.

The ability to produce siderophore was qualitatively determined by using the modified chrome azurol S (CAS) solution according to Alexander and Zuberer (1991). The standard curve for the determination of siderophore concentration was prepared by diluting $1 \mathrm{mM} \mathrm{FeCl}_{3}$ into $100 \mathrm{~mL}$ of the CAS solution, with the final concentrations of $0,0.005$, $0.01,0.015,0.03 \mathrm{mM} \mathrm{FeCl}_{3}$ in CAS solution. The concentration of siderophore in the culture filtrates was screened by mixing $50 \mu \mathrm{L}$ bacterial supernatant with $100 \mu \mathrm{L}$ CAS solution containing $0.015 \mathrm{mM} \mathrm{FeCl}_{3}$ (modified CAS solution) in a 96-well microtiter plate. The mixtures and the standard curve were equilibrated for 3-4 h and the amount of consumed $\mathrm{FeCl}_{3}$ in the mixture considered as the proxy of siderophore production - was subsequently determined by measuring absorbance at $630 \mathrm{~nm}$ with an automated microplate reader (Bio-Tek Instruments).

\footnotetext{
${ }^{1}$ https://blast.ncbi.nlm.nih.gov/Blast.cgi
}

IAA production was determined colorimetrically (Gordon and Weber, 1951; Glickmann et al., 1995). Briefly, $10 \mu \mathrm{L}$ of bacterial supernatant was mixed with $15 \mu \mathrm{L}$ of Salkowskireagent $\left(1.2 \% \mathrm{FeCl}_{3}\right.$ in $37 \% \mathrm{H}_{2} \mathrm{SO}_{4}$ ) (ratio bacterial supernatant to Salkowski-reagent $1: 1.5$ ) in a 96-well microtiter plate, and the mixture was incubated overnight at room temperature. The colorations from yellow to purple indicating IAA production were then measured at $535 \mathrm{~nm}$. The amount of IAA presented in the supernatant was determined by comparing the observed data to a standard curve generated by diluting synthetic IAA to concentrations between $10^{-6}$ and $10^{-4}$.

Exoprotease activity was quantitatively measured by azocasein colorimetry method, modified from Smeltzer et al. (1992). Briefly, $15 \mu \mathrm{L}$ culture supernatant was mixed with $25 \mu \mathrm{L}$ of $2 \%$ azocasein in a 96-well microtiter plate, and the mixture was incubated at $40^{\circ} \mathrm{C}$ for $24 \mathrm{~h}$. Then $125 \mu \mathrm{L}$ of $10 \%$ Tricholoracetic acid (TCA) was added the mixture. After centrifugation ( $5 \mathrm{k} \mathrm{rpm}$ for $30 \mathrm{~min}$ ), $100 \mu \mathrm{L}$ of the supernatant was neutralized with $100 \mu \mathrm{L}$ of $1 \mathrm{M}$ $\mathrm{NaOH}$ in a new microtiter plate, followed by the colorimetric measurement at $440 \mathrm{~nm}$.

Biofilm formation was screened using the microtiter plate biofilm assay modified from O’Toole and Kolter (1998). Briefly, bacterial strains were inoculated into 96-well microtiter plates containing $200 \mu \mathrm{L}$ of $\mathrm{LB}$ medium and incubated at $25^{\circ} \mathrm{C}$ for 2 days, reaching the stationary phase. Subsequently, $150 \mu \mathrm{L}$ bacterial culture were transferred to new 96-well microtiter plates, covered with a lid with pegs (TSP, NUNC, Roskilde, Denmark) and the plates were incubated for $24 \mathrm{~h}$ at room temperature to allow biofilm formation. Next, the pegs with biofilm were washed in a tray with $1 \mathrm{X}$ PBS (five times) to remove bacterial cells, and stained for $20 \mathrm{~min}$ in $160 \mu \mathrm{L}$ of $1 \%$ crystal violet solution. The peg was then transferred to a microtiter plate with $200 \mu \mathrm{L} 96 \%$ ethanol and incubated for $20 \mathrm{~min}$. The crystal violet concentration in ethanol representing biofilm formation was measured by absorbance at $590 \mathrm{~nm}$.

\section{Bacterial Fitness Traits}

For screening the bacterial fitness traits, bacterial cultures growing to the stationary phase were used (see PGP traits for details). For each microtiter plate, negative controls were included by adding LB medium without bacterial culture together with other reagents.

Biotic stress resistance was measured by determining the resistance to the antibiotics of streptomycin derived from Streptomyces (bacteria) and the fungal secreted penicillin. Specifically, $2 \mu \mathrm{L}$ of bacterial cells were transferred to individual wells on a 96-well microtiter plate containing $160 \mu \mathrm{L}$ LB medium and the antibiotics, at final concentration of $1 \mu \mathrm{g} / \mathrm{mL}$. Plates were incubated for 2 days at $25^{\circ} \mathrm{C}$, when bacterial growth was measured at the wavelength of $600 \mathrm{~nm}$.

Abiotic stress resistance was measured by screening the resistance to different $\mathrm{pH}$ values $(\mathrm{pH}=5,6,8,9)$, salinity (final concentration of $\mathrm{NaCl}, \mathrm{w} / \mathrm{v} 7$ and $10 \%$ ), oxidative (final concentration of $\mathrm{H}_{2} \mathrm{O}_{2}, 0.00025$ and $0.0005 \%$ ) and osmotic (15\% Polyethylene glycol Mn6000 PEG) stress. Similarly to the previous tests, $2 \mu \mathrm{L}$ of bacterial cells were transferred to individual wells on a 96-well microtiter plate containing $160 \mu \mathrm{L}$ 
LB medium and the respective reagent. Incubation period and plate reading was performed as for biotic stress.

\section{Metabolic Potential Determined by Growth on Different Carbon Sources}

To test the effect of different types of carbon sources on the bacterial growth, 14 carbon sources including Alanine, Arabinose, Butyrolactam (2-Pyrrolidone), Fructose, Galactose, Glucose, Glycerol, Glycine, Lactic Acid, Putrescine, Serine, Succin Acid, Threonine, Valine were used and incorporated individually into modified OSG medium (minimal medium containing all salts required for bacterial growth) (SchniderKeel et al., 2000) (15 $\mu \mathrm{L}$ carbon source into $135 \mu \mathrm{L}$ modified OSG medium) at the final concentration of $0.05 \%(w / v)$. After inoculation of $5 \mu \mathrm{L}$ bacterial culture into the $150 \mu \mathrm{L}$ modified OSG medium containing corresponding carbon source onto a 96-well microtiter plate, followed by incubation for 2 days at $25^{\circ} \mathrm{C}$, growth was measured by absorbance at $600 \mathrm{~nm}$. For each microtiter plate, negative controls were included by adding LB medium without bacterial culture together with the other reagents.

\section{Data Analysis}

The statistical analyses in this study were performed in $\mathrm{R}$ environment $^{2}$ ( $R$ Core Team, 2013). CFU values were log transformed before statistical analysis. Significant differences in $\log (\mathrm{CFU})$ across plant compartments, plant species, and soil types were identified using three-way analysis of variance (ANOVA) (function aov), followed by multiple comparisons (function TukeyHSD) in multcomp package (Hothorn et al., 2008). Prior to ANOVA analyses, normality of the dataset was tested by using base function sapply() modified by adding the function mystats by Kabacoff (2015), while homogeneity of variances was verified by using the function fligner() in $\mathrm{R}$.

The data associated with the functional traits (biochemical assays) were subjected to a range of normalizations. First, the absorbance values obtained for bacterial fitness (abiotic and biotic resistance) and metabolic potential (growth in 14 carbon sources) were normalized by the absorbance of the bacterial growth in LB medium without other reagents at the stationary phase. Traits associated with bacterial fitness were further weighted to account for the relative abundance of each strain in the original samples. This was achieved by multiplying the absorbance data by the relative abundance of each strain, i.e., the ratio of the number of colonies identified as a specific strain to the total number of colonies obtained from the corresponding treatment. For the traits associated with the metabolic potential, the normalized data were further standardized by the maximum absorbance value observed across all carbon sources and used to calculate the niche breadth for each bacterial isolate, by summing all 14 values according to Salles et al. (2009). Regarding the traits associated with plant growth promotion, which are based on bacterial supernatant, the absorbance values were only weighted to account for the relative abundance of each strain in the original samples, as described above.

\footnotetext{
${ }^{2}$ http://www.r-project.org
}

In order to show the variation of functionality along the chronosequence, the variation of individual functional traits along the chronosequence were simulated using polynominal regression performed in polynom package (Venables et al., 2016) and plotted in ggplot2 package (Wickham, 2009), and only the significant regressions were shown. The polynomial regression was used to verify the distribution of traits along the chronosequence containing five successional stages, as previously done for data referring to plant diversity and biomass, bacterial diversity and microbial activities (Schrama et al., 2013; DiniAndreote et al., 2014, 2015; Wang et al., 2016; Salles et al., 2017). To test for correlations between bacterial growth under $\mathrm{pH}$ and salinity stress and the variations of soil $\mathrm{pH}$ and salinity along the succession, we applied Spearman's rankbased correlational analysis. The distribution of functional traits performed by isolates from different successional stages and plant compartments was performed by principal components analysis (PCA), using the built-in R function prcomp(). Values of the individual functional traits were log transformed before PCA. The visualization of the PCA results was conducted by using the function ggbiplot() in the packages ggbiplot (Vincent, 2011).

To further verify the overall patterns of functional diversity, we generated functional diversity measure encompassing all the quantified traits, by modifications from Laliberté and Legendre (2010). A matrix containing all normalized data on individual trait for each species was used to calculate the pairwise distance between species based on Bray Curtis distance. We then calculated the average pairwise distance for each treatment (plant compartment, plant species and soil type) by pooling the treatment-specific species together. The pairwise comparisons for the overall functional diversity between two stages were tested by using Post hoc test (function posthoc.kruskal.nemenyi.test) in PMCMR package (Pohlert, 2014) after Kruskal-Wallis test.

The strength of each functional trait associated with the bacterial isolates from different plant compartments, plant species and soil types were visualized by using heatmap (function aheatmap) in NMF package (Gaujoux, 2015; Seoighe, 2015). Prior to analysis, the normalized absorbance values were further standardized by using $Z$-scores. Pie charts were used to summarize the proportion of bacterial isolates from one of the treatments.

\section{RESULTS}

\section{Isolation, Screening and Characterization of Plant-Associated Bacteria in Rhizosphere and Root Endosphere}

The population counts on R2A agar plates of bacterial isolates from the rhizosphere soil and root endosphere of $L$. vulgare and A. maritima along the chronosequence were significantly influenced by soil type $(F=10.820, P=0.002)$. Significant differences in population counts were respectively observed between middle (15- and 35-year stages) and late (65- and 105-year stages) successional phases for either rhizosphere 


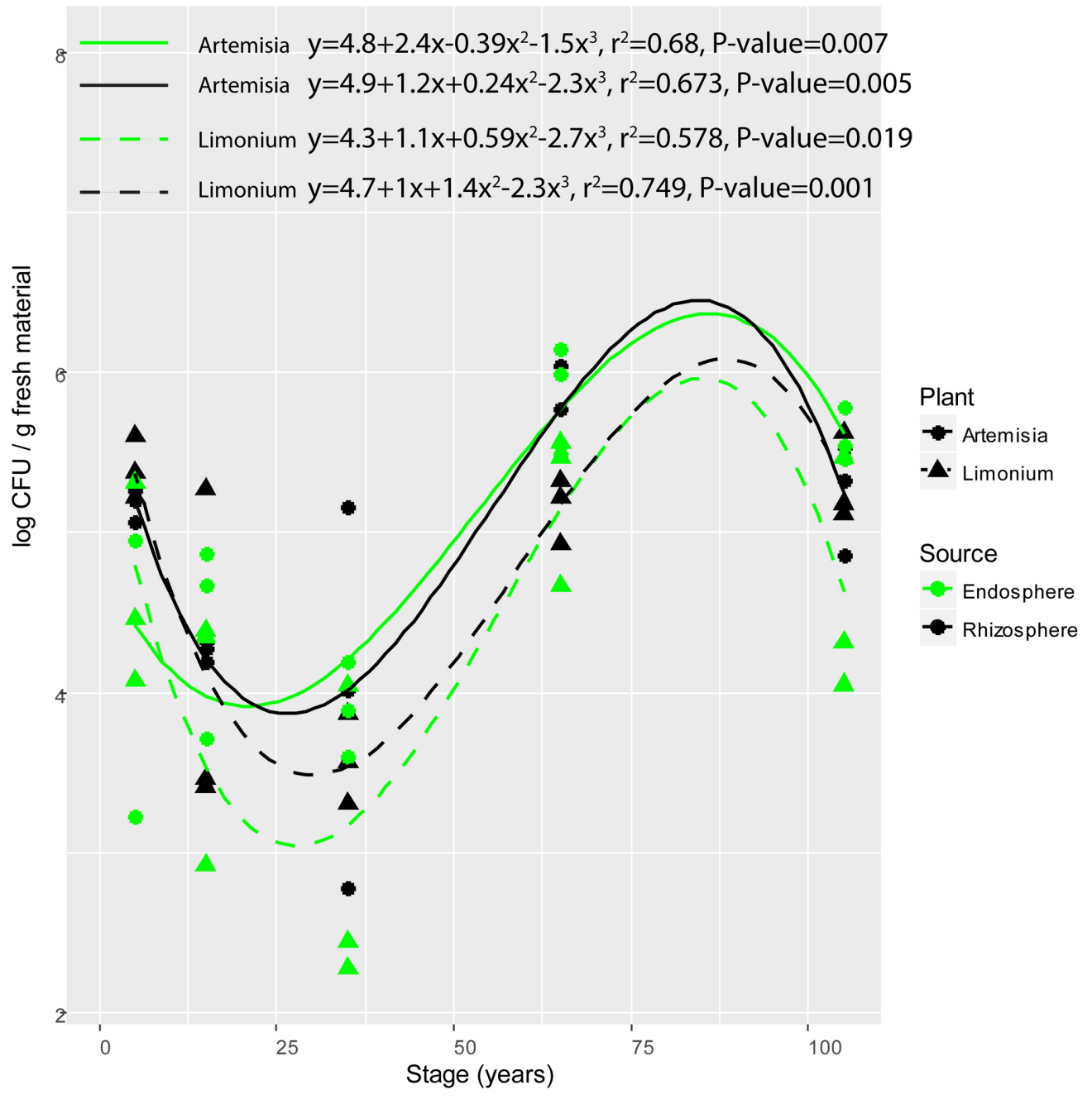

FIGURE 1 | Variation of colony forming units (CFU) of root-associated bacterial isolates along the chronosequence. For plant species, solid and dashed line represent A. maritima and L. vulgare, respectively. For plant compartments, black refer to rhizosphere isolates whereas green represent those obtained from the endosphere.

or endosphere from both plants (Tukey's HSD test, for L. vulgare, rhizosphere, $P=0.012$, endosphere, $P=0.008$; for A. maritima, rhizosphere, $P=0.013$, endosphere, $P=0.001)$. In addition, significant polynomial variations were found for either compartment from both plant species (Figure 1), respectively decreasing from the initial (5-year stage) to middle phase followed by an increase toward the late phase along the chronosequence.

In order to foster variation among isolates, up to 30 colonies differing in morphology were recovered from each treatment, generating a total of 808 colonies. These were characterized by genotypic characterization using BOX-PCR, which targets repeated regions across the bacterial genome, therefore depicting differences at strain level (thus beyond $16 \mathrm{~S}$ rRNA gene identification, Cho and Tiedje, 2000). The BOX-PCR analyses indicated that these 808 colonies could be assigned to 159 bacterial genotypes (strains) with unique BOX-PCR patterns (Supplementary Figure S1 and Table S1), which were further identified at species level by sequencing of the 16S rRNA gene, revealing a set of 68 unique bacterial species (Supplementary Table S2). From those, 59 species were unique to individual treatments and further functionally characterized using biochemical assays targeting a range of traits. The remaining 9 strains were observed in more than one plant compartment or plant species (Hafnia psychrotolerans strain CSE_16, Pseudomonas sp. CanL-3, Pseudomonas sp. 332, Pseudomonas sp. UT 6-06, Pseudomonas sp. ARCTIC-P37, Pseudomonas sp. JY-Q, Pseudomonas sp. 46 (2016), Pseudomonas fluorescens strain FW300-N2E2, and Serratia fonticola strain 51) and therefore not included to avoid biases in the analyses (Supplementary Figure S2).

According to phylogenetic analyses, the 59 unique strains were affiliated with six taxonomic groups (Supplementary Figure S3). Gammaproteobacteria was the predominant class with 45 unique strains included, from which $33.3 \%$ of the strains were isolated from the 65-year stage while the remaining ones were almost 

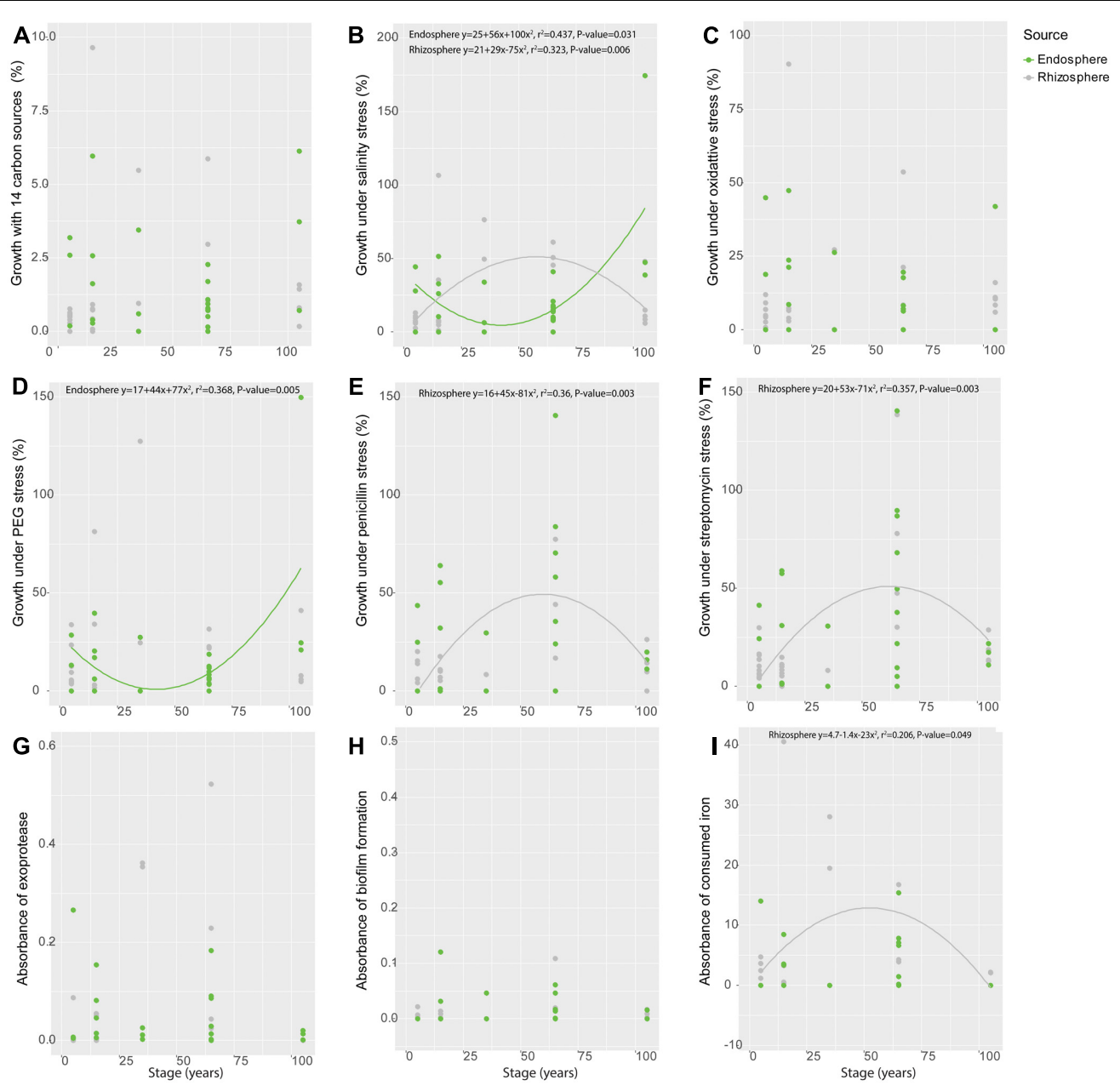

FIGURE 2 | Variation of functional traits of bacterial isolates from rhizosphere and endosphere along the chronosequence. (A) Metabolic potential, (B) Salinity stress resistance, (C) Oxidative stress resistance, (D) Osmotic stress resistance, (E) Penicillin resistance, (F) Streptomycin resistance, (G) Exoprotease production, (H) Biofilm production and (I) Siderophore production. Gray color refer to rhizosphere isolates whereas green represent those obtained from the endosphere.

evenly distributed among other stages. Moreover, the strains belonging to Gammaproteobacteria were equally isolated from either plant species or plant compartment (Supplementary Figure S4). Actinobacteria was the second dominant phylum including 6 unique strains, from which 3 strains were obtained from 5-year stage. Among these Actinobacteria isolates, 66.7\% were from A. maritima, among which $75 \%$ were from rhizosphere. The strains affiliated with Bacilli (two isolates) and Bacteroidetes (four isolates) were all isolated from the rhizosphere of A. maritima, whereas the single Alpha- and Beta-proteobacteria isolates were from the endosphere of L. vulgare. Specifically, the strains belonging to Bacteroidetes, Alpha- and Beta-proteobacteria were only isolated from 5-year stage. Thus, the diversity of bacterial isolates was highest at 5-year stage including five taxonomic groups (16 unique strains), among which Gammaproteobacteria accounted for almost half of the total amount of strains (Supplementary Figure S5). Whereas the lowest taxonomic diversity was observed at 65-year stage, where 14 out of 15 isolated strains were affiliated with Gammaproteobacteria.

\section{Dynamics of Biochemical Properties of Plant-Associated Bacteria in Response to the Chronosequence}

When analyzed along time - as represented by the different soil stages along the primary succession - some of the individual functional traits showed significant patterns along the chronosequence. Specifically, isolates obtained from the rhizosphere showed a hump-shaped distribution for salinity stress resistance $\left(r^{2}=0.323, P=0.006\right)$ and siderophore production $\left(r^{2}=0.206, P=0.049\right)$, peaking at the 35 -year stage (Figures 2B,I). The salinity stress resistance strongly correlated with soil salinity, whose variation progressively increases along the succession (Wang et al., 2016) (spearman correlation, $P=0.005$; polynomial regression, $r^{2}=0.219, P=0.042$ ) (Supplementary Figure S6). Similarly, hump-shaped tendencies were found for antibiotics resistance (penicillin: $r^{2}=0.360$, $P=0.003$; streptomycin: $r^{2}=0.357, P=0.003$ ), but those traits peaked later in the succession, at the 65-year stage (Figures 2E,F). 

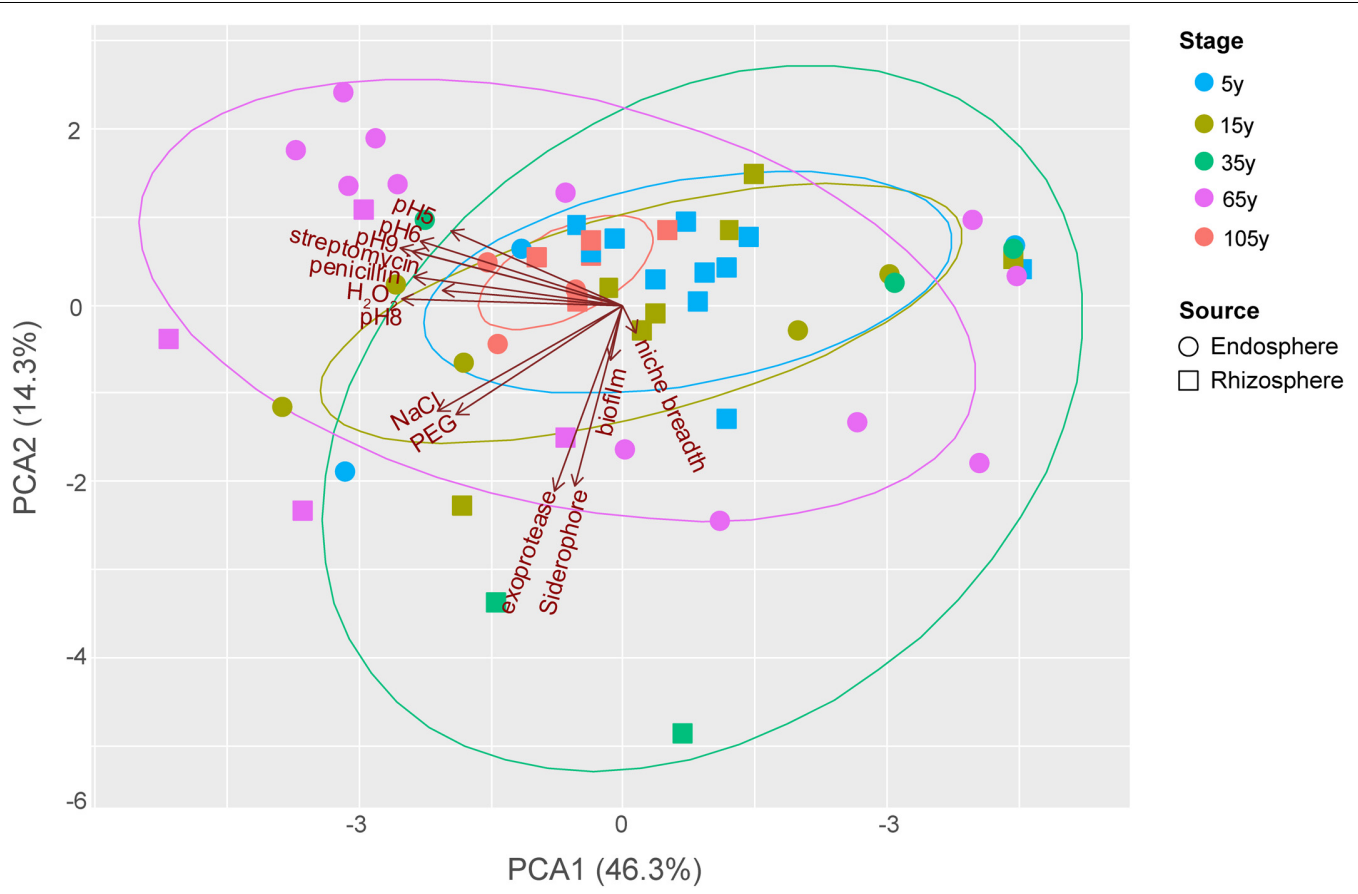

FIGURE 3 | Principal components analysis (PCA) biplot of the functionalities of bacterial isolates from different plant compartments along the chronosequence. For successional stages, blue, light beige, green, purplish red and orange color represent 5, 15, 35, 65 and 105-year stage, respectively. For plant compartments, square refer to rhizosphere isolates whereas circle represent those obtained from the endosphere.

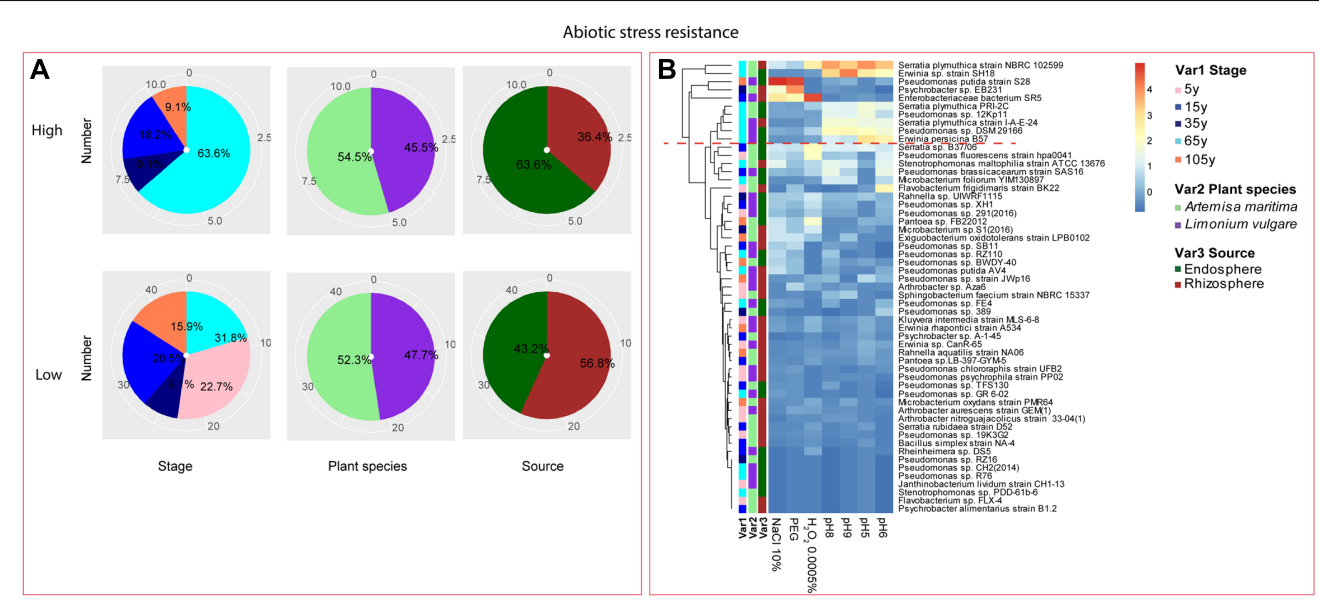

FIGURE 4 | Distribution of abiotic stress resistance of root-associated bacterial strains. (A) Distribution of isolates from different treatments according to high and low activities in abiotic stress resistance. (B) Heatmap profiles for abiotic stress resistance of all isolates. The annotation of treatments - successional stages, plant species and plant compartments were respectively referred as Var1, Var2 and Var3. For successional stages, pink, blue, navy, cyan and orange color represent 5 , $15,35,65$, and 105-year stage, respectively. For plant species, purple refers to $L$. vulgare and green to $A$. maritima. For plant compartments, red refer to rhizosphere and green to endosphere isolates. The blue-red gradient bar represents the normalized absorbance values (Z-scores). Only the integer scaled values (0-4) were shown alongside the color bar. The red dashed line separates the high and low bacterial functional profiles, which were determined by the cluster assignment based on the average Euclidean distance among the bacterial strains.

Regarding the isolates obtained from the endosphere, we only found significant patterns for resistance to salinity $\left(r^{2}=0.437\right.$, $P=0.031)$ and osmotic stress $\left(r^{2}=0.368, P=0.005\right)$ along the chronosequence (Figures 2B,D), showing a reverse humpshaped pattern with a slight decrease from the initial stage to 65-year stage followed by a sharp increase toward 105-year stage, while other traits were relatively constant across the succession (Figures 2A,C,E-I). For both rhizosphere and endosphere, no significant trend of bacterial growth under different $\mathrm{pH}$ was observed (Supplementary Figures S7, S8). 


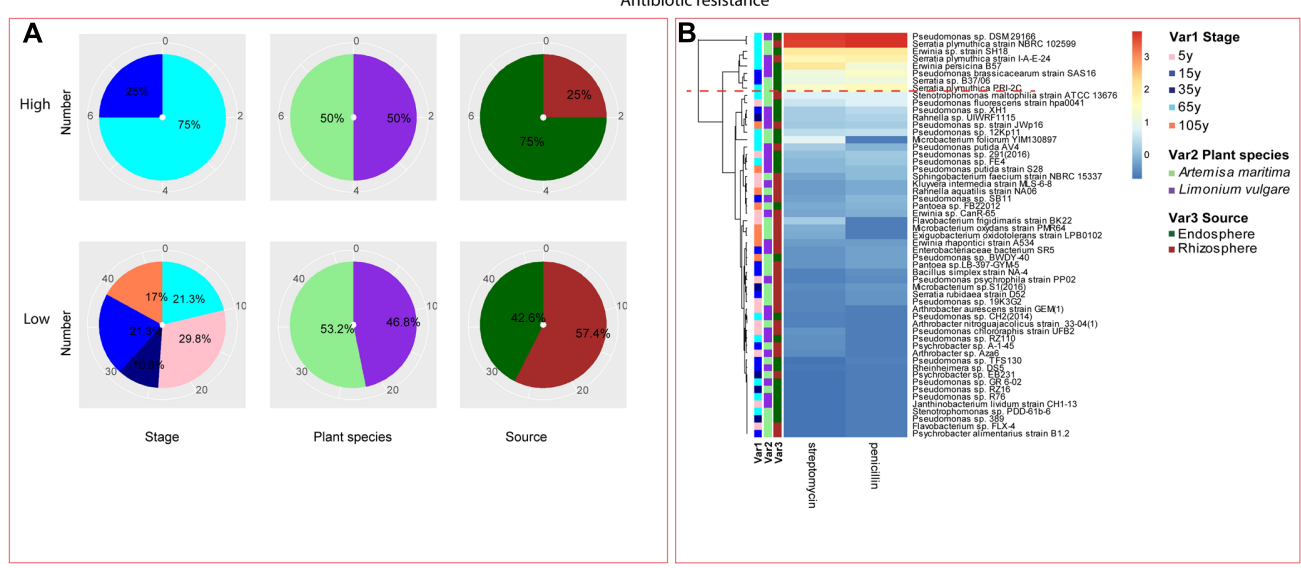

FIGURE 5 | Distribution of antibiotic resistance of root-associated bacterial strains. (A) Distribution of isolates from different treatments according to high and low activities in antibiotic resistance. (B) Heatmap profiles for antibiotic resistance of all isolates. The annotation of treatments - successional stages, plant species and plant compartments and corresponding colors are the same with those in Figure 4. The blue-red gradient bar represents the normalized absorbance values (Z-scores). Only the integer scaled values (0-3) were shown alongside the color bar. The red dashed line separates the high and low bacterial functional profiles, which were determined by the cluster assignment based on the average Euclidean distance among the bacterial strains.

A

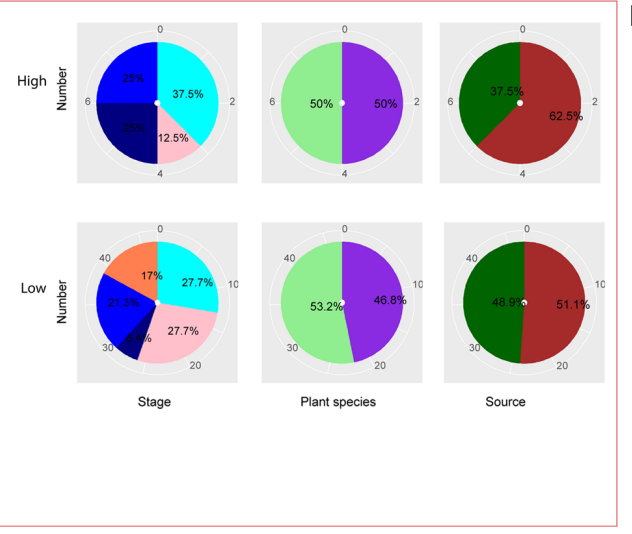

Plant associated traits

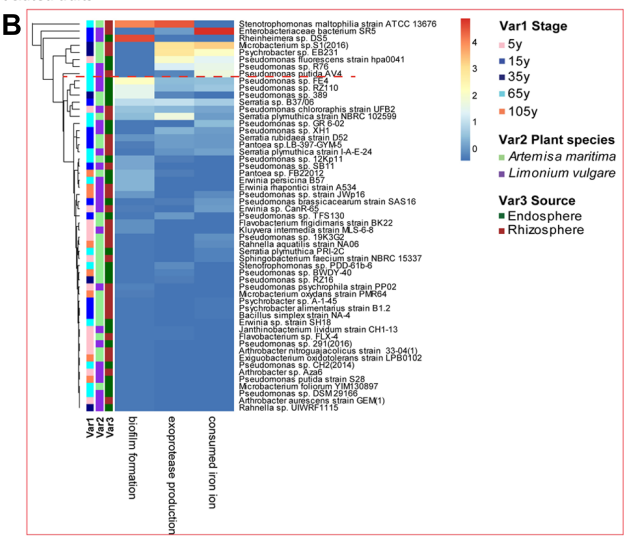

FIGURE 6 | Distribution of plant growth promoting traits of root-associated bacterial strains. (A) Distribution of isolates from different treatments according to high and low growth profiles in plant growth promoting traits (biofilm formation, production of exoprotease and siderophore). (B) Heatmap profiles for plant growth promoting traits of all isolates. The annotation of treatments - successional stages, plant species and plant compartments and corresponding colors are the same with those in Figure 4. The blue-red gradient bar represents the normalized absorbance values (Z-scores). Only the integer scaled values (0-4) were shown alongside the color bar. The red dashed line separates the high and low bacterial functional profiles, which were determined by the cluster assignment based on the average Euclidean distance among the bacterial strains.

\section{Variation in Functional Diversity along the Chronosequence}

The functional trait patterns obtained from the bacterial isolates from different plant compartments across the succession were represented using multivariate analyses (PCA, Figure 3). PC1 and PC2 accounted for $60.67 \%$ of the total variance among all traits tested in this study, largely reflecting the functionalities of bacterial isolates. PC1 was mostly represented by antibiotic resistance, and growth under different $\mathrm{pH}$ (especially $\mathrm{pH}=6,8,9$ ). PC2 was mainly represented by production of exoprotease and siderophore. In addition, resistance to salinity stress is associated with a PC3 (not shown), given the $45^{\circ}$ angle with both $\mathrm{PC} 1$ and PC2.

The distributional pattern of functional traits of bacterial isolates from each stage was unique. Stage 105 year showed the most restricted distribution among others as most of these strains performed relatively low functionalities (Figure 3), except for two endosphere isolates showing relatively high growth level under different $\mathrm{pH}$ as well as resistance to salinity and osmotic stress. Conversely, the isolates from stage 35 year showed a broad functionality, given their great dispersion in the PCA. Among these small number of strains with high functional profiles, one rhizosphere isolates showed high production of exoprotease 

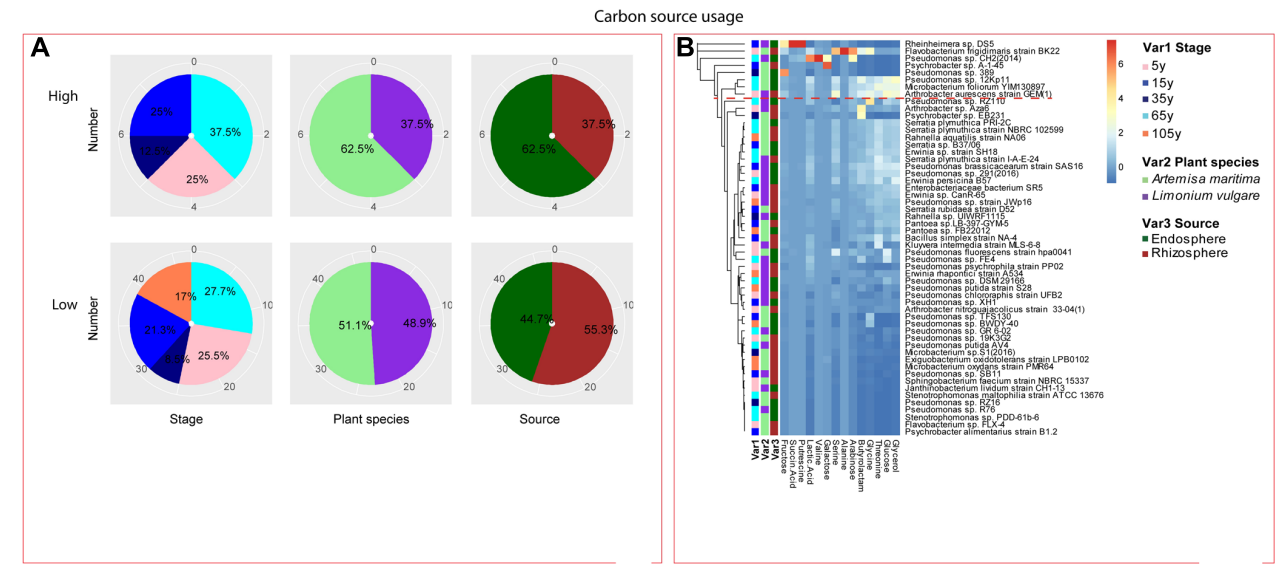

FIGURE 7 | Distribution of metabolic potential of root-associated bacterial strains. (A) Distribution of isolates from different treatments according to high and low growth profiles in metabolic potential. (B) Heatmap profiles for metabolic potential of all isolates. The annotation of treatments - successional stages, plant species and plant compartments and corresponding colors are the same with those in Figure 4. The blue-red gradient bar represents the normalized absorbance values (Z-scores). Only the integer scaled values (0-6) were shown alongside the color bar. The red dashed line separates the high and low bacterial functional profiles, which were determined by the cluster assignment based on the average Euclidean distance among the bacterial strains.

and siderophore, whereas one endosphere isolate was found to show high resistance to antibiotics and high growth level under different $\mathrm{pH}$. Similarly, the dispersion level of isolates from 65-year stage was also high. However, a large number of these isolates, which are mostly endophytes, showed high growth level under different $\mathrm{pH}$, while two rhizosphere isolates were found to perform high resistance to salinity and osmotic stress as well as the production of exoprotease and siderophore. The dispersion level of isolates from 5- and 15-year stages was moderate compared to others. In addition, most of the isolates these two stages showed relatively low functional profiles, except for one endosphere isolate with high antibiotic resistance and two other endosphere isolates with high resistance to salinity and osmotic stress from 15-year stage.

Among the isolates showing high biochemical properties, which were mostly from 65-year stage, Pseudomonas sp. DSM29166, Serratia plymuthica strain NBRC102599, Serratia plymuthica PRI-2C, Serratia plymuthica strain I-A-E-24, Erwinia sp. strain SH18, and Erwinia persicina B57 showed both resistance to abiotic stress and antibiotics (Figures 4, 5). Strains showing high functional profile in plant associated traits were also largely from 65 -year stage $(37.5 \%)$ compared to other stages, including Pseudomonas sp. R76, Pseudomonas putida AV4 and Stenotrophomonas maltophilia strain ATCC 13676 (Figure 6). Similarly, a larger proportion of the isolates showing high metabolic potential were from 65-year stage (37.5\%) compared to others, including Pseudomonas sp. CH2(2014), Pseudomonas sp. 12Kp11 and Microbacterium foliorum YIM130897 (Figure 7).

To further verify the patterns of functional diversity, we generated functional diversity measures encompassing all the traits measured, allowing us to depict functional similarity among species along a continuum of soil formation as a whole (total functional diversity) or per category of function (specific functional diversity): traits associated with bacterial fitness (antibiotic and abiotic stress resistance - $\mathrm{pH}$, osmotic and oxidative stress, and salinity), metabolic potential determined by growth on different carbon sources, and PGP capacity (siderophore production, exoprotease production and biofilm formation).

Analyzes of variance indicated soil type exerted significant influence on total functional diversity $(P=0.035)$, but not on that for bacterial isolates from either plant compartment $(P>0.05)$ (Table 1). In addition, the total functional diversity at the 35-year stage was higher compared with the initial and late stages, confirming the broad distribution observed in the PCA. When grouping the functional traits according to soil stages, we observed that soil type influenced the functional trait diversity associated with antibiotics resistance $(P=0.014)$ in rhizosphere with a significant enrichment at the 35 -year stage, whereas for endophytes, none of the diversity of functional traits was affected by stage $(P>0.05)$ (Table 1). Plant species exerted significant effect on the functional diversity related to resistance against abiotic stress, metabolic potential and PGP capacity (respectively, $P=0.004, P=0.001, P=0.049$ ) (Table 2). Moreover, the total functional diversity of isolates obtained from $L$. vulgare followed the development of succession, peaking at the 15 -year stage (Table 1).

\section{DISCUSSION}

The plant-associated microbiome is one of the key determinants of plant health and productivity (Daane et al., 2001; Penrose and Glick, 2003; Lugtenberg and Kamilova, 2009; Yang et al., 2009; Gayathri et al., 2010; Berg et al., 2014), playing an important role in plant phenotypic and epigenetic plasticity and further evolution (Partida-Martínez and Heil, 2011). It is therefore crucial to unravel the factors influencing the functionality of plant microbiome (Berg and Smalla, 2009; Berg et al., 2014), which varies in response to both soil properties and plant species 
TABLE 1 | Functional diversity indices for different successional stages.

\begin{tabular}{|c|c|c|c|c|}
\hline Traits & Source & Stage & $\begin{array}{c}\text { Functional } \\
\text { diversity }\end{array}$ & $\begin{array}{c}P \text {-value } \\
\text { (K-W test) }\end{array}$ \\
\hline \multirow[t]{5}{*}{ Total } & \multirow{5}{*}{$\begin{array}{l}\text { Both rhizosphere } \\
\text { and endosphere }\end{array}$} & 5 year & $0.69 \pm 0.23$ & \multirow[t]{5}{*}{$0.035^{*}$} \\
\hline & & 15 year & $0.71 \pm 0.31$ & \\
\hline & & 35 year & $0.88 \pm 0.17$ & \\
\hline & & 65 year & $0.64 \pm 0.32$ & \\
\hline & & 105 year & $0.61 \pm 0.25$ & \\
\hline \multirow[t]{10}{*}{ Total } & \multirow[t]{5}{*}{ Rhizosphere } & 5 year & $0.71 \pm 0.24$ & \multirow[t]{5}{*}{0.504} \\
\hline & & 15 year & $0.73 \pm 0.34$ & \\
\hline & & 35 year & $0.64 \pm 0.00$ & \\
\hline & & 65 year & $0.61 \pm 0.21$ & \\
\hline & & 105 year & $0.63 \pm 0.28$ & \\
\hline & \multirow[t]{5}{*}{ Endosphere } & 5 year & $0.67 \pm 0.32$ & \multirow[t]{5}{*}{0.520} \\
\hline & & 15 year & $0.73 \pm 0.27$ & \\
\hline & & 35 year & $0.98 \pm 0.03$ & \\
\hline & & 65 year & $0.65 \pm 0.33$ & \\
\hline & & 105 year & $0.63 \pm 0.17$ & \\
\hline \multirow[t]{10}{*}{ Total } & \multirow[t]{5}{*}{ Artemisia maritima } & 5 year & $0.85 \pm 0.20$ & \multirow[t]{5}{*}{0.141} \\
\hline & & 15 year & $0.72 \pm 0.34$ & \\
\hline & & 35 year & $0.93 \pm 0.13$ & \\
\hline & & 65 year & $0.56 \pm 0.36$ & \\
\hline & & 105 year & $0.73 \pm 0.17$ & \\
\hline & \multirow[t]{5}{*}{ Limonium vulgare } & 5 year & $0.56 \pm 0.20$ & \multirow[t]{5}{*}{$0.02 *$} \\
\hline & & 15 year & $0.75 \pm 0.24$ & \\
\hline & & 35 year & N.A. & \\
\hline & & 65 year & $0.69 \pm 0.28$ & \\
\hline & & 105 year & $0.33 \pm 0.08$ & \\
\hline \multirow{10}{*}{$\begin{array}{l}\text { Plant associate } \\
\text { traits }\end{array}$} & \multirow[t]{5}{*}{ Rhizosphere } & 5 year & $0.75 \pm 0.31$ & \multirow[t]{5}{*}{0.255} \\
\hline & & 15 year & $0.74 \pm 0.33$ & \\
\hline & & 35 year & $0.18 \pm 0.00$ & \\
\hline & & 65 year & $0.69 \pm 0.32$ & \\
\hline & & 105 year & $0.85 \pm 0.29$ & \\
\hline & \multirow[t]{5}{*}{ Endosphere } & 5 year & $0.73 \pm 0.39$ & \multirow[t]{5}{*}{0.189} \\
\hline & & 15 year & $0.78 \pm 0.33$ & \\
\hline & & 35 year & $0.77 \pm 0.12$ & \\
\hline & & 65 year & $0.86 \pm 0.25$ & \\
\hline & & 105 year & $0.75 \pm 0.22$ & \\
\hline \multirow{10}{*}{$\begin{array}{l}\text { Abiotic stress } \\
\text { resistance }\end{array}$} & \multirow[t]{5}{*}{ Rhizosphere } & 5 year & $0.43 \pm 0.16$ & 0.459 \\
\hline & & 15 year & $0.56 \pm 0.25$ & \\
\hline & & 35 year & $0.50 \pm 0.00$ & \\
\hline & & 65 year & $0.48 \pm 0.15$ & \\
\hline & & 105 year & $0.40 \pm 0.15$ & \\
\hline & Endosphere & 5 year & $0.35 \pm 0.00$ & 0.364 \\
\hline & & 15 year & $0.65 \pm 0.24$ & \\
\hline & & 35 year & $0.74 \pm 0.00$ & \\
\hline & & 65 year & $0.50 \pm 0.24$ & \\
\hline & & 105 year & $0.51 \pm 0.14$ & \\
\hline Antibiotic & Rhizosphere & 5 year & $0.47 \pm 0.19$ & $0.014^{*}$ \\
\hline resistance & & 15 year & $0.32 \pm 0.15$ & \\
\hline & & 35 year & $0.98 \pm 0.00$ & \\
\hline & & 65 year & $0.43 \pm 0.16$ & \\
\hline & & 105 year & $0.34 \pm 0.15$ & \\
\hline & Endosphere & 5 year & $0.26 \pm 0.00$ & 0.060 \\
\hline & & 15 year & $0.68 \pm 0.35$ & \\
\hline
\end{tabular}

TABLE 1 | Continued

\begin{tabular}{lcccc}
\hline Traits & Source & Stage & $\begin{array}{c}\text { Functional } \\
\text { diversity }\end{array}$ & $\begin{array}{c}\boldsymbol{P} \text {-value } \\
\text { (K-W test) }\end{array}$ \\
\hline & 35 year & N.A. & \\
& 65 year & $0.66 \pm 0.29$ & \\
& 105 year & $0.20 \pm 0.08$ & \\
Metabolic & Rhizosphere & 5 year & $0.66 \pm 0.22$ & 0.995 \\
potential & & 15 year & $0.61 \pm 0.38$ & \\
& & 35 year & $0.71 \pm 0.00$ & \\
& & 65 year & $0.70 \pm 0.28$ & \\
& & 105 year & $0.66 \pm 0.30$ & \\
& & 5 year & $0.66 \pm 0.32$ & 0.071 \\
& Endosphere & 5 year & $0.73 \pm 0.26$ & \\
& & 35 year & N.A. & \\
& 65 year & $0.47 \pm 0.29$ & \\
& 105 year & $0.69 \pm 0.24$ & \\
& & &
\end{tabular}

N.A., not applicable; ${ }^{*} P<0.05$.

(Garbeva et al., 2004b; Jousset et al., 2006; Berg and Smalla, 2009). Each plant species is thought to select specific microbial populations from soil through the driving force exerted by root exudates (Smalla et al., 2006; Faure et al., 2009; Cibichakravarthy et al., 2012). However, the plant selective force varies according to differences in agricultural practices, sampling sites or soil type, in order of importance (Garbeva et al., 2004b; Costa et al., 2006; Salles et al., 2006; Inceoğlu et al., 2010), although the effect of the latter is usually confounded with microbial biogeographical patterns. In this study, we disentangled the effect that soil and plant species exert on the functionality of bacteria isolated from rhizosphere and endosphere of two salt marsh plants, $L$. vulgare and A. maritima, by sampling along a natural gradient of soil formation that is exposed to the same microbial meta-community (Olff et al., 1997; Dini-Andreote et al., 2014, 2015; Wang et al., 2016). The absence of functional diversity pattern of isolates obtained from endosphere along the chronosequence would indicate plant selectivity to be stronger than the soil influence, whereas an increased complexity of functional diversity patterns associated with rhizosphere isolates along the succession would reveal an overriding effect of soil type over plant species.

\section{Taxonomic Distribution of Root-Associated Bacterial Isolates}

From the taxonomic characteristics, most of the bacterial isolates were unique to one plant species or plant compartment (Supplementary Figure S2), which coincided with the effect of plant selectivity, recruiting unique microbes in response to the specific root exudates produced by different plants (Hartmann et al., 2009; Berendsen et al., 2012) and the degree of association with plant host, given the different biochemical environment observed in the internal root tissues (Gaiero et al., 2013; Timm et al., 2015). Specifically, this selectivity was obvious for the non-dominant groups - Bacilli, Bacteroidetes, Alpha- and Betaproteobacteria, probably because of the low number of isolated species associated with these classes. We 
observed a predominance of Gammaproteobacteria, especially belonging to the genus Pseudomonas, in our isolates despite the utilization of general isolation media. Similar results have been found elsewhere (Marilley and Aragno, 1999; Haas and Défago, 2005; Bharathkumar et al., 2008; Hong et al., 2013), which could be explained by the important functions that the genus Pseudomonas provides for plant hosts, such as plant growth promotion (Patten and Glick, 2002; Berg and Smalla, 2009; Rashid et al., 2012) and biological control (Chin-A-Woeng et al., 2003; Garbeva et al., 2004b; Beneduzi et al., 2012). The absolute predominance of Gammaproteobacteria from 65-year stage (Supplementary Figure S5) was also confirmed in our previous study on the rhizosphere of $L$. vulgare where more unique OTUs belonging to Gammaproteobacteria (a total of 99) were found at 65-year stage compared to other stages (Wang et al., 2016). These results could serve as an inference of a more stabilized community structure toward the end of succession, being in accordance with the reduced community turnover in rhizosphere (Wang et al., 2016), possibly resulting from the dominance of buffering effects of soil as well as plants following the development of succession (Walker and del Moral, 2003; Dini-Andreote et al., 2014). Despite the low number of individuals belonging to other classes, it is interesting to note that the highest diversity of other taxonomic groups was observed at the initial stage, which is subjected to a constant influx of different microbes owing to marine input (Dini-Andreote et al., 2014), followed by colonization in the different plant compartments.

\section{Functional Dynamics of the Rhizosphere Bacterial Isolates along the Chronosequence}

The isolates obtained from the rhizosphere showed significant patterns along the chronosequence, specially for functions associated with bacterial fitness, indicating their response to soil properties as well as their potential to improve plant health. Specifically, the progressively increasing pattern of salinity stress resistance, antibiotic resistance and siderophore production of bacterial isolates were in line with the soil salinity accumulation

TABLE 2 | Comparison of functional diversity indices between two plant species.

\begin{tabular}{llcc}
\hline Traits & \multicolumn{1}{c}{$\begin{array}{c}\text { Plant } \\
\text { species }\end{array}$} & $\begin{array}{c}\text { Functional } \\
\text { diversity }\end{array}$ & $\begin{array}{c}\text { P-value } \\
\text { (K-W test) }\end{array}$ \\
\hline Total & $\begin{array}{c}\text { Artemisia maritima } \\
\text { Limonium vulgare }\end{array}$ & $\begin{array}{c}0.76 \pm 0.26 \\
0.59 \pm 0.27\end{array}$ & $0.001^{* * *}$ \\
Plant associate traits & Artemisia maritima & $0.83 \pm 0.79$ & $0.049^{*}$ \\
& Limonium vulgare & $0.25 \pm 0.31$ & \\
Abiotic stress resistance & Artemisia maritima & $0.59 \pm 0.20$ & $0.004^{* *}$ \\
& Limonium vulgare & $0.55 \pm 0.19$ & \\
Antibiotic resistance & Artemisia maritima & $0.60 \pm 0.26$ & 0.388 \\
& Limonium vulgare & $0.58 \pm 0.29$ & \\
Metabolic potential & Artemisia maritima & $0.69 \pm 0.30$ & $0.001^{* * *}$ \\
& Limonium vulgare & $0.30 \pm 0.27$ & \\
\hline
\end{tabular}

${ }^{*} P<0.05 ;{ }^{* *} P<0.01 ;{ }^{* * *} P<0.001$. and soil nutrients enrichment following the development of succession (Dini-Andreote et al., 2015; Wang et al., 2016). Moreover, it confirms the metagenomics data generated from bulk soil samples collected from the same field, where we observed an increase in genes associated with both salinity stress and antibiotic resistance at the end of the chronosequence (Dini-Andreote et al., 2017, submitted). These traits associated with antibiotic resistance are believed to play an important role in the adaptation of microbes to complex-structured environments like the soils found at the late successional stages. Despite the concurrence between studies, it is important to notice that the patterns observed in this study are obtained for a limited number of isolates and that an increase in the survey could lead to changes in the patterns. For instance, we expect that the difference between different plant compartments and plant species would be decreased, considering that more bacteria performing similar functions would be isolated. Below we discuss the most significant results obtained by grouping the bacterial isolates according to their specific functional diversity.

\section{Bacterial Fitness (Antibiotic and Abiotic Stress Resistance)}

In the context of salinity stress, the strains showing high resistance were isolated from the middle and late succession, and among them, Pseudomonas genus accounted for a large portion, which was consistent with the findings of Egamberdieva et al. (2008), who showed that the genus Pseudomonas and Bacillus could promote wheat growth in saline soils of Uzbekistan. Nadeem et al. (2016) also found that the rhizobacteria strain Pseudomonas fluorescens was the best strain for maintaining PGP traits under stressed conditions and alleviating the negative impacts of salinity on cucumber growth. Additionally, three Serratia sp. strains were also observed to show high salinity tolerance. This genus has been previously reported as capable of dealing with salt stress, which is the case of the strain Serratia sp. GSD2, which could sustain growth medium containing up to $10 \% \mathrm{NaCl}$, together with the increasing biofilm and extracellular enzyme production following the salinity increase (Mendpara et al., 2013). Regarding the resistance to biotic stress, strains belonging to genus Serratia showed high antibiotic resistance at late succession, which could indicate the general antifungal and antiparasitic properties often observed by this genus (Kalbe et al., 1996; Grimont and Grimont, 2006). Similarly, one Pseudomonas sp. strain from late stage also showed high antibiotic resistance, which was consistent with the high antagonistic activity found in other studies (Berg et al., 2002, 2006; Haas and Keel, 2003; Raaijmakers et al., 2010).

\section{Plant Growth Promoting Capacity (Siderophore and Exoprotease Production, Biofilm Formation)}

Siderophores are important traits associated with the plant microbiome, by competitively inhibiting the growth of plant pathogens or other harmful rhizosphere microbes with efficient Fe uptake system (Klopper, 1980; Sidhu et al., 1997; Bevivino et al., 1998; Maksimov et al., 2011; Gaiero et al., 2013; Ahmed 
and Holmström, 2014). Therefore, the increasing siderophore production observed in the rhizosphere isolates along the chronosequence may be also as a result of the shifts in microbial composition following the development of succession (Dini-Andreote et al., 2014, 2016), which might be associated with higher microbial competition, as siderophore production could confer competitive advantages to rhizosphere-associated bacteria (Haas and Défago, 2005). Three Pseudomonas sp. strains were found to produce relatively more siderophores among others, which was confirmed by many studies related to siderophore production by Pseudomonas genus for plant growth promotion or biocontrol function against plant pathogen (Crosa, 1997; Dwivedi and Johri, 2003; Sharma and Johri, 2003; Sasirekha and Shivakumar, 2016). A pseudobactin siderophore produced by $P$. putida B10 strain was able to suppress Fusarium oxysporum in iron-deficient soil (Klopper, 1980). Additionally, Bar-Ness et al. (1991) found that ferrated $\left({ }^{59} \mathrm{Fe}\right)$ pseudobactin (PSB) $\left({ }^{59} \mathrm{FePSB}\right)$ - a Pseudomonas putida siderophore could be more efficiently assimilated by plants compared with FeEDDHA, which was also proved by other studies (Masalha et al., 2000; Katiyar and Goel, 2004; Dimkpa et al., 2009).

\section{Functional Dynamics of the Endosphere Bacterial Isolates along the Chronosequence}

Contrary to the rhizosphere isolates, the majority of functions associated with endophytes, except for resistance to salinity and osmotic stress, remained constant along the chronosequence, confirming our hypothesis that plant selectivity would be stronger in these communities. Thus, the selectivity and the buffering effect offered by plants against abiotic and biotic stresses (Hallmann et al., 1997; Rosenblueth and Martínez-Romero, 2006; Schulz and Boyle, 2006) lead to a stable community structure (Wang et al., 2016) and further functional profile for the root endophytes. Interestingly, the resistance against salinity and osmotic stress dramatically increased at the 105year stage, which was in line with the community turnover of endophytes observed earlier when assessing L. vulgareassociated bacterial communities through molecular methods (Wang et al., 2016). This could be derived from the stress experienced by both $L$. vulgare and A. maritima because of the higher salinity level and severe competition with other plants at the late stage, specially Elytrigia atherica, which dominates the vegetation (Schrama et al., 2012). The reason why these two traits were synchronized in response to the soil and plant changes along the succession could be explained by the inhibitory effect of salt on plant growth, causing both ion toxicity and osmotic stress (Zhang et al., 2010; Tavakkoli et al., 2011).

\section{Functional Diversity of the Plant Microbiome}

By disentangling the distributional pattern of functional traits from different treatments and by grouping the functional traits into an overall functional diversity measure we observed that the functional diversity of bacterial isolates was highest at intermediate stages of succession. We could speculate that the intermediate soil nutritional level, intermediate stressful abiotic (salinity, higher flooding frequency) and biotic environment (plant competition) at the stage could lead to a selection of more versatile root-associated bacteria that can better adapt to and cope with the variety of biotic and abiotic conditions, eventually leading to an enrichment of functional diversity in the intermediate succession. This high functional diversity was, however, not associated with the taxonomic diversity, which was highest at early stages of succession. The screening of a larger number of isolates should provide a better characterization of the potential (lack of) link between taxonomy and function, which should be the subject of follow up studies. For instance, the screening of larger number of strains from the initial stage could eventually increase the functional diversity patterns, which should lead to a larger dispersion in Figure 3. However, given the low functional variation observed despite the high taxonomic diversity, we argue that is not likely to occur. Likewise, the screening a larger number of isolates should not modify the observed high functional diversity assigned to intermediate stage. The lowest functional diversity was observed in the 105-year stage, characterized by high soil nutrient content, plant biomass and low environmental fluctuations. We speculate that this low variability in abiotic and biotic stress lead to a more stable, functionally specialized microbiome. We expect that this pattern would remain the same if more isolates would be screened, given that the bacterial isolates in the dominant taxonomic group at this stage are closely related in phylogeny. Additionally, the plant species exerted an influence on the root-associated bacterial functional diversity which was higher in the A. maritima microbiome, which mainly derived from the difference of root exudates from different plants (Hartmann et al., 2009; Bednarek et al., 2010; Berendsen et al., 2012), resulting in plant specificity of microbial communities (Haichar et al., 2008; Berg and Smalla, 2009; Turner et al., 2013; Ofek-Lalzar et al., 2014).

\section{CONCLUSION}

Overall, this study provides key information on the variation in functionality of bacterial isolates associated with rhizosphere and endosphere of L. vulgare and A. maritima along a salt marsh primary succession chronosequence. We could show that the importance of soil in driving the functional diversity of root-associated bacterial isolates is dependent on the plant compartments, being influential only in the rhizosphere but not on the endosphere. Interestingly, the intermediate successional stage exhibits the highest functional trait diversity associated with antibiotics resistance of rhizobacterial isolates. While the constant distribution of functional diversity of endosphere isolates indicates a strong plant selective force and buffering effect on endophytes. Specifically, we could show that some Pseudomonas sp. and Serratia sp. strains reveal high resistance to abiotic stress and antibiotics and produce more siderophores, confirming the high PGP activity of these two genera. Additionally, the distinctive distribution of taxonomic groups 
according to specific plant compartment or plant species validates the existence of the plant selective force on the root-associated microbes, resulting in the distinctive taxonomy composition and diversity in the rhizosphere and the internal root tissues and among different plant species.

\section{AUTHOR CONTRIBUTIONS}

MW participated in study design, took samples, did the experiments and write the manuscript. EL contributed to the modified methods for biochemical tests in this study. CL helped with the main experimental part of biochemical tests. AJ provided his lab for conducting the biochemical tests and discussed about the results in the manuscript. JS supervised the project and participated in the decision of every part in the manuscript.

\section{REFERENCES}

Ahmed, E., and Holmström, S. J. M. (2014). Siderophores in environmental research: roles and applications. Microb. Biotechnol. 7, 196-208. doi: 10.1111/ 1751-7915.12117

Alexander, D. B., and Zuberer, D. A. (1991). Use of chrome azurol S reagents to evaluate siderophore production by rhizosphere bacteria. Biol. Fertil. Soils 12, 39-45. doi: 10.1007/BF00369386

Bar-Ness, E., Chen, Y., Hadar, Y., Marschner, H., and Römheld, V. (1991). Siderophores of Pseudomonas putida as an iron source for dicot and monocot plants. Plant Soil 130, 231-241. doi: 10.1007/BF00011878

Bednarek, P., Kwon, C., and Schulze-Lefert, P. (2010). Not a peripheral issue: secretion in plant-microbe interactions. Curr. Opin. Plant Biol. 13, 378-387. doi: 10.1016/j.pbi.2010.05.002

Beneduzi, A., Ambrosini, A., and Passaglia, L. M. P. (2012). Plant growthpromoting rhizobacteria (PGPR): their potential as antagonists and biocontrol agents. Genet. Mol. Biol. 35, 1044-1051. doi: 10.1590/S141547572012000600020

Berendsen, R. L., Pieterse, C. M. J., and Bakker, P. A. H. M. (2012). The rhizosphere microbiome and plant health. Trends Plant Sci. 17, 478-486. doi: 10.1016/j. tplants.2012.04.001

Berg, G., Grube, M., Schloter, M., and Smalla, K. (2014). Unraveling the plant microbiome: looking back and future perspectives. Front. Microbiol. 5:148. doi: $10.3389 /$ fmicb.2014.00148

Berg, G., Opelt, K., Zachow, C., Lottmann, J., Götz, M., Costa, R., et al. (2006). The rhizosphere effect on bacteria antagonistic towards the pathogenic fungus Verticillium differs depending on plant species and site. FEMS Microbiol. Ecol. 56, 250-261. doi: 10.1111/j.1574-6941.2005.00025.x

Berg, G., Roskot, N., Steidle, A., Eberl, L., Zock, A., and Smalla, K. (2002). Plantdependent genotypic and phenotypic diversity of antagonistic rhizobacteria isolated from different Verticillium host plants plant-dependent genotypic and phenotypic diversity of antagonistic rhizobacteria isolated from different Verticillium Host. Appl. Environ. Microbiol. 68, 3328-3338. doi: 10.1128/AEM. 68.7.3328

Berg, G., and Smalla, K. (2009). Plant species and soil type cooperatively shape the structure and function of microbial communities in the rhizosphere. FEMS Microbiol. Ecol. 68, 1-13. doi: 10.1111/j.1574-6941.2009. 00654.x

Bevivino, A., Sarrocco, S., Dalmastri, C., Tabacchioni, S., Cantale, C., and Chiarini, L. (1998). Characterization of a free-living maize-rhizosphere population of Burkholderia cepacia: effect of seed treatment on disease suppression and growth promotion of maize. FEMS Microbiol. Ecol. 27, 225-237. doi: 10.1016/S0168-6496(98)00069-5

Bharathkumar, S., Paul, D., and Nair, S. (2008). Microbial diversity of culturable heterotrophs in the rhizosphere of salt marsh grass, Porteresia coarctata (Tateoka) in a mangrove ecosystem. J. Basic Microbiol. 48, 10-15. doi: 10.1002/ jobm.200700282

\section{ACKNOWLEDGMENTS}

We thank Han Olff, Matty Berg, Chris Smit, Maarten Schrama, and Ruth Howison for information on sampling locations and plant species. We are grateful to Jolanda K. Brons and Armando Cavalcante Franco Dias for sampling expeditions. We thank the 'Nederlandse Vereniging voor Natuurmonumenten' for granting us access to the salt marsh. This work was supported by China Scholarship Council, on a personal grant to MW.

\section{SUPPLEMENTARY MATERIAL}

The Supplementary Material for this article can be found online at: https://www.frontiersin.org/articles/10.3389/fmicb. 2017.02102/full\#supplementary-material

Brusetti, L., Malkhazova, I., Gtari, M., Tamagnini, I., Borin, S., Merabishvili, M., et al. (2008). Fluorescent-BOX-PCR for resolving bacterial genetic diversity, endemism and biogeography. BMC Microbiol. 8:220. doi: 10.1186/1471-21808-220

Cavalli-Sforza, L. L., and Edwards, A. W. F. (1967). Phylogenetic analysis models and estimation procedures. Am. J. Hum. Genet. 19, 233-257. doi: 10.2307/ 2406616

Chin-A-Woeng, T. F. C., Bloemberg, G. V., and Lugtenberg, B. J. J. (2003). Phenazines and their role in biocontrol by Pseudomonas bacteria. New Phytol. 157, 503-523. doi: 10.1046/j.1469-8137.2003.00686.x

Cho, J.-C., and Tiedje, J. M. (2000). Biogeography and degree of endemicity of fluorescent Pseudomonas strains in soil. Appl. Environ. Microbiol. 66, 5448-5456. doi: 10.1128/AEM.66.12.5448-5456.2000

Cibichakravarthy, B., Preetha, R., Sundaram, S. P., Kumar, K., and Balachandar, D. (2012). Diazotrophic diversity in the rhizosphere of two exotic weed plants, Prosopis juliflora and Parthenium hysterophorus. World J. Microbiol. Biotechnol. 28, 605-613. doi: 10.1007/s11274-011-0853-9

Compant, S., Clément, C., and Sessitsch, A. (2010). Plant growth-promoting bacteria in the rhizo- and endosphere of plants: their role, colonization, mechanisms involved and prospects for utilization. Soil Biol. Biochem. 42, 669-678. doi: 10.1016/j.soilbio.2009.11.024

Compant, S., Reiter, B., Sessitsch, A., Clément, C., Barka, E. A., and Nowak, J. (2005). Endophytic colonization of Vitis vinifera L. by plant growthpromoting bacterium Burkholderia sp. strain PsJN. Appl. Environ. Microbiol. 71, 1685-1693. doi: 10.1128/AEM.71.4.1685

Costa, R., Götz, M., Mrotzek, N., Lottmann, J., Berg, G., and Smalla, K. (2006). Effects of site and plant species on rhizosphere community structure as revealed by molecular analysis of microbial guilds. FEMS Microbiol. Ecol. 56, 236-249. doi: 10.1111/j.1574-6941.2005.00026.x

Crosa, J. H. (1997). Signal transduction and transcriptional and posttranscriptional control of iron-regulated genes in bacteria. Microbiol. Mol. Biol. Rev. 61, 319-336.

Daane, L. L., Harjono, I., Zylstra, G. J., and Häggblom, M. M. (2001). Isolation and characterization of polycyclic aromatic hydrocarbon-degrading bacteria associated with the rhizosphere of salt marsh plants. Appl. Environ. Microbiol. 67, 2683-2691. doi: 10.1128/AEM.67.6.2683

de Bello, F., Berg, M., Dias, A., Diniz-Filho, J., Götzenberger, L., Hortal, J., et al. (2015). On the need for phylogenetic 'corrections' in functional trait-based approaches. Folia Geobot. 50, 349-357. doi: 10.1007/s12224-015-9228-6

Dimkpa, C. O., Merten, D., Svatoš, A., Büchel, G., and Kothe, E. (2009). Metal-induced oxidative stress impacting plant growth in contaminated soil is alleviated by microbial siderophores. Soil Biol. Biochem. 41, 154-162. doi: 10.1016/j.soilbio.2008.10.010

Dini-Andreote, F., Pereira e Silva, M. D. C., Triado, X., Casamayor, E. O., van Elsas, J. D., and Salles, J. F. (2014). Dynamics of bacterial community succession in a salt marsh chronosequence: evidences for temporal niche partitioning. ISME J. 8, 1989-2001. doi: 10.1038/ismej.2014.54 
Dini-Andreote, F., Pylro, V. S., van Elsas, J. D., and Salles, J. F. (2016). Ecological succession reveals potential signatures of marine-terrestrial transition in salt marsh fungal communities. ISME J. 10, 1984-1997. doi: 10.1038/ismej.2015.254

Dini-Andreote, F., Stegen, J. C., van Elsas, J. D., and Salles, J. F. (2015). Disentangling mechanisms that mediate the balance between stochastic and deterministic processes in microbial succession. Proc. Natl. Acad. Sci. U.S.A. 112, 1326-1332. doi: 10.1073/pnas.1414261112

Dwivedi, D., and Johri, B. N. (2003). Antifungals from fluorescent pseudomonads: biosynthesis and regulation. Curr. Sci. 85, 1693-1703.

Edwards, U., Rogall, T., Blöcker, H., Emde, M., and Böttger, E. C. (1989). Isolation and direct complete nucleotide determination of entire genes. Characterization of a gene coding for 16S ribosomal RNA. Nucleic Acids Res. 17, 7843-7853. doi: 10.1093/nar/17.19.7843

Egamberdieva, D., Kamilova, F., Validov, S., Gafurova, L., Kucharova, Z., and Lugtenberg, B. (2008). High incidence of plant growth-stimulating bacteria associated with the rhizosphere of wheat grown on salinated soil in Uzbekistan. Environ. Microbiol. 10, 1-9. doi: 10.1111/j.1462-2920.2007.01424.x

Ellis, R. J., Morgan, P., Weightman, A. J., and Fry, J. C. (2003). Cultivationdependent and independent approaches for determining bacterial diversity in heavy-metal-contaminated soil. Appl. Environ. Microbiol. 69, 3223-3230. doi: 10.1128/AEM.69.6.3223-3230.2003

Faure, D., Vereecke, D., and Leveau, J. H. J. (2009). Molecular communication in the rhizosphere. Plant Soil 321, 279-303. doi: 10.1007/s11104-008-9839-2

Felsenstein, J. (1981). Evolutionary trees from DNA sequences: a maximum likelihood approach. J. Mol. Evol. 17, 368-376. doi: 10.1007/BF01734359

Felsenstein, J. (1993). Phylogeny Inference Package (PHYLIP). Version 3.5. Seattle, WA: University of Washington.

Gaiero, J. R., McCall, C. A., Thompson, K. A., Day, N. J., Best, A. S., and Dunfield, K. E. (2013). Inside the root microbiome: bacterial root endophytes and plant growth promotion. Am. J. Bot. 100, 1738-1750. doi: 10.3732/ajb.1200572

Garbeva, P., van Veen, J. A., and van Elsas, J. D. (2004a). Assessment of the diversity, and antagonism towards Rhizoctonia solani AG3, of Pseudomonas species in soil from different agricultural regimes. FEMS Microbiol. Ecol. 47, 51-64. doi: 10.1016/S0168-6496(03)00234-4

Garbeva, P., van Veen, J. A., and van Elsas, J. D. (2004b). Microbial diversity in soil: selection microbial populations by plant and soil type and implications for disease suppressiveness. Annu. Rev. Phytopathol. 42, 243-270. doi: 10.1146/ annurev.phyto.42.012604.135455

Gaujoux, R. (2015). Algorithms and Framework for Nonnegative Matrix Factorization (NMF) CRAN. R package version 0.20.6. Available at: http://cran. r-project.org/package $=\mathrm{NMF}$

Gayathri, S., Saravanan, D., Radhakrishnan, M., Balagurunathan, R., and Kathiresan, K. (2010). Bioprospecting potential of fast growing endophytic bacteria from leaves of mangrove and salt-marsh plant species. Indian J. Biotechnol. 9, 397-402.

Glickmann, E., Dessaux, Y., Glickmann, E., and Dessaux, Y. (1995). A critical examination of the specificity of the salkowski reagent for indolic compounds produced by phytopathogenic bacteria. Appl. Environ. Microbiol. 61, 793-796.

Gordon, S. A., and Weber, R. P. (1951). Colorimetric estimation of indoleacetic acid. Plant Physiol. 26, 192-195. doi: 10.1104/pp.26.1.192

Grimont, F., and Grimont, P. A. D. (2006). The genus Serratia. Prokaryotes 6, 219-244. doi: 10.1007/0-387-30746-X_11

Haas, D., and Défago, G. (2005). Biological control of soil-borne pathogens by fluorescent pseudomonads. Nat. Rev. Microbiol. 3, 307-319. doi: 10.1038/ nrmicro1129

Haas, D., and Keel, C. (2003). Regulation of antibiotic production in root colonizing Pseudomonas spp., and relevance for biological control of plant disease. Annu. Rev. Phytopathol. 79, 117-153. doi: 10.1146/annurev.phyto.41. 052002.095656

Haichar, F. Z., Marol, C., Berge, O., Rangel-Castro, J. I., Prosser, J. I., Balesdent, J., et al. (2008). Plant host habitat and root exudates shape soil bacterial community structure. ISME J. 2, 1221-1230. doi: 10.1038/ismej.2008.80

Hallmann, J., Quadt-Hallmann, A., Mahaffee, W. F., and Kloepper, J. W. (1997). Bacterial endophytes in agricultural crops. Can. J. Microbiol. 43, 895-914. doi: $10.1139 / \mathrm{m} 97-131$

Hardoim, P. R., van Overbeek, L. S., and van Elsas, J. D. (2008). Properties of bacterial endophytes and their proposed role in plant growth. Trends Microbiol. 16, 463-471. doi: 10.1016/j.tim.2008.07.008
Hartmann, A., Schmid, M., van Tuinen, D., and Berg, G. (2009). Plant-driven selection of microbes. Plant Soil 321, 235-257. doi: 10.1007/s11104-008-9814-y

Hong, Y., Liao, D., Hu, A., Wang, H., Chen, J., Khan, S., et al. (2013). Diversity of endophytic and rhizoplane bacterial communities associated with exotic Spartina alterniflora and native mangrove using Illumina amplicon sequencing. Can. J. Microbiol. 733, 1-32. doi: 10.1139/cjm-2015

Hothorn, T., Bretz, F., and Westfall, P. (2008). Simultaneous inference in general parametric models. Biom. J. 50, 346-363. doi: 10.1002/bimj.200 810425

Hussain, Q., Liu, Y., Jin, Z., Zhang, A., Pan, G., Li, L., et al. (2011). Temporal dynamics of ammonia oxidizer ( $a m o A)$ and denitrifier (nirK) communities in the rhizosphere of a rice ecosystem from Tai Lake region, China. Appl. Soil Ecol. 48, 210-218. doi: 10.1016/j.apsoil.2011.03.004

Inceoğlu, Ö, Salles, J. F., van Overbeek, L., and van Elsas, J. D. (2010). Effects of plant genotype and growth stage on the betaproteobacterial communities associated with different potato cultivars in two fields. Appl. Environ. Microbiol. 76, 3675-3684. doi: 10.1128/AEM.00040-10

Jousset, A., Lara, E., Wall, L. G., and Valverde, C. (2006). Secondary metabolites help biocontrol strain Pseudomonas fluorescens CHA0 to escape protozoan grazing. Appl. Environ. Microbiol. 72, 7083-7090. doi: 10.1128/AEM.00557

Kabacoff, R. (2015). $R$ in Action: Data Analysis and Graphics with $R, 2$ nd Edn. New York, NY: Manning Publications.

Kalbe, C., Marten, P., and Berg, G. (1996). Strains of the genus Serratia as beneficial rhizobacteria of oilseed rape with antifungal properties. Microbiol. Res. 151, 433-439. doi: 10.1016/S0944-5013(96)80014-0

Katiyar, V., and Goel, R. (2004). Siderophore mediated plant growth promotion at low temperature by mutant of fluorescent pseudomonad. Plant Growth Regul. 42, 239-244. doi: 10.1023/B:GROW.0000026477.10681.d2

Klopper, A. (1980). "Placental metabolism," in Clinical Physiology in Obstetrics, eds F. Hytten and G. Chamberlain (Oxford: Blackwell Scientific Publications), 441-467.

Kumar, S., Stecher, G., and Tamura, K. (2016). MEGA7: Molecular Evolutionary Genetics Analysis version 7.0 for bigger datasets. Mol. Biol. Evol. 33:msw054. doi: 10.1093/molbev/msw054

Laliberté, E., and Legendre, P. (2010). A distance-based framework for measuring functional diversity from multiple traits. Ecology 91, 299-305. doi: 10.1890/082244.1

Lane, D. (1991). “16S/23S rRNA sequencing," in Nucleic Acid Techniques in Bacterial Systematics, eds E. Stackebrandt and M. Goodfellow (New York, NY: John Wiley \& Sons), 115-147.

Lauber, C. L., Strickland, M. S., Bradford, M. A., and Fierer, N. (2008). The influence of soil properties on the structure of bacterial and fungal communities across land-use types. Soil Biol. Biochem. 40, 2407-2415. doi: 10.1016/j.soilbio. 2008.05.021

Letunic, I., and Bork, P. (2011). Interactive tree of life v2: online annotation and display of phylogenetic trees made easy. Nucleic Acids Res. 39, 475-478. doi: 10.1093/nar/gkr201

Lugtenberg, B., and Kamilova, F. (2009). Plant-growth-promoting rhizobacteria. Annu. Rev. Microbiol. 63, 541-556. doi: 10.1146/annurev.micro.62.081307. 162918

Lundberg, D. S., Lebeis, S. L., Paredes, S. H., Yourstone, S., Gehring, J., Malfatti, S., et al. (2012). Defining the core Arabidopsis thaliana root microbiome. Nature 488, 86-90. doi: 10.1038/nature 11237

Maksimov, I. V., Abizgil'dina, R. R., and Pusenkova, L. I. (2011). Plant growth promoting rhizobacteria as alternative to chemical crop protectors from pathogens (review). Appl. Biochem. Microbiol. 47, 333-345. doi: 10.1134/ S0003683811040090

Marilley, L., and Aragno, M. (1999). Phylogenetic diversity of bacterial communities differing in degree of proximity of Lolium perenne and Trifolium repens roots. Appl. Soil Ecol. 13, 127-136. doi: 10.1016/S0929-1393(99) 00028-1

Marschner, P., Yang, C.-H., Lieberei, R., and Crowley, D. E. (2001). Soil and plant specific effects on bacterial community composition in the rhizosphere. Soil Biol. Biochem. 33, 1437-1445. doi: 10.1016/S0038-0717(01) 00052-9

Masalha, J., Kosegarten, H., Elmaci, Ö, and Mengel, K. (2000). The central role of microbial activity for iron acquisition in maize and sunflower. Biol. Fertil. Soils 30, 433-439. doi: 10.1007/s003740050021 
Mendes, L. W., Tsai, S. M., Navarrete, A. A., de Hollander, M., van Veen, J. A., and Kuramae, E. E. (2015). Soil-borne microbiome: linking diversity to function. Microb. Ecol. 70, 255-265. doi: 10.1007/s00248-014-0559-2

Mendpara, J., Parekh, V., Vaghela, S., Makasana, A., Prashant, D., Sanghvi, G., et al. (2013). Isolation and characterization of high salt tolerant bacteria from agricultural soil. Eur. J. Exp. Biol. 3, 351-358.

Nadeem, S. M., Ahmad, M., Naveed, M., Imran, M., Zahir, Z. A., and Crowley, D. E. (2016). Relationship between in vitro characterization and comparative efficacy of plant growth-promoting rhizobacteria for improving cucumber salt tolerance. Arch. Microbiol. 198, 379-387. doi: 10.1007/s00203-016-1197-5

Nannipieri, P., Ascher, J., Ceccherini, M. T., Landi, L., Pietramellara, G., and Renella, G. (2003). Microbial diversity and soil functions. Eur. J. Soil Sci. 54, 655-670. doi: 10.1111/ejss.4_12398

Ofek-Lalzar, M., Sela, N., Goldman-Voronov, M., Green, S. J., Hadar, Y., and Minz, D. (2014). Niche and host-associated functional signatures of the root surface microbiome. Nat. Commun. 5, 4950. doi: 10.1038/ncomms5950

Olff, H., de Leeuw, J., Bakker, J. P., Platerink, R. J., and van Wijnen, H. J. (1997). Vegetation succession and herbivory in a salt marsh: changes induced by sea level rise and silt deposition it along an elevational gradient. J. Ecol. 85, 799-814. doi: $10.2307 / 2960603$

O’Toole, G. A., and Kolter, R. (1998). Flagellar and twitching motility are necessary for Pseudomonas aeruginosa biofilm development. Mol. Microbiol. 30, 295-304. doi: 10.1046/j.1365-2958.1998.01062.x

Partida-Martínez, L. P., and Heil, M. (2011). The microbe-free plant: fact or artifact? Front. Plant Sci. 2:100. doi: 10.3389/fpls.2011.00100

Patten, C. L., and Glick, B. R. (2002). Role of Pseudomonas putida indoleacetic acid in development of the host plant root system. Appl. Environ. Microbiol. 68, 3795-3801. doi: 10.1128/AEM.68.8.3795

Penrose, D. M., and Glick, B. R. (2003). Methods for isolating and characterizing ACC deaminase-containing plant growth-promoting rhizobacteria. Physiol. Plant. 118, 10-15. doi: 10.1034/j.1399-3054.2003.00086.x

Pohlert, T. (2014). The Pairwise Multiple Comparison of Mean Ranks Package (PMCMR). $R$ Package. Available at: http://CRAN.R-project.org/package= PMCMR

Quast, C., Pruesse, E., Yilmaz, P., Gerken, J., Schweer, T., Yarza, P., et al. (2013). The SILVA ribosomal RNA gene database project: improved data processing and web-based tools. Nucleic Acids Res. 41, 590-596. doi: 10.1093/nar/gks1219

R Core Team (2013). R: A Language and Environment for Statistical Computing. Vienna: R Foundation for Statistical Computing.

Raaijmakers, J. M., de Bruijn, I., Nybroe, O., and Ongena, M. (2010). Natural functions of lipopeptides from Bacillus and Pseudomonas: more than surfactants and antibiotics. FEMS Microbiol. Rev. 34, 1037-1062. doi: 10.1111/ j.1574-6976.2010.00221.x

Rasche, F., Trondl, R., Naglreiter, C., Reichenauer, T. G., and Sessitsch, A. (2006). Chilling and cultivar type affect the diversity of bacterial endophytes colonizing sweet pepper (Capsicum annuum L.). Can. J. Microbiol. 52, 1036-1045. doi: 10.1139/w06-059

Rashid, S., Charles, T. C., and Glick, B. R. (2012). Isolation and characterization of new plant growth-promoting bacterial endophytes. Appl. Soil Ecol. 61, 217-224. doi: 10.1016/j.apsoil.2011.09.011

Ribeiro, C. M., and Cardoso, E. J. B. N. (2012). Isolation, selection and characterization of root-associated growth promoting bacteria in Brazil Pine (Araucaria angustifolia). Microbiol. Res. 167, 69-78. doi: 10.1016/j.micres.2011. 03.003

Rosenblueth, M., and Martínez-Romero, E. (2006). Bacterial endophytes and their interactions with hosts. Mol. Plant. Microbe. Interact. 19, 827-837. doi: 10.1094/ MPMI-19-0827

Rovira, A. D. (1956). Plant root excretions in relation to the rhizosphere effect. Plant Soil 7, 178-194. doi: 10.1007/BF01343726

Saleem, M., Law, A. D., and Moe, L. A. (2015). Nicotiana roots recruit rare rhizosphere taxa as major root-inhabiting microbes. Microb. Ecol. 71, 469-472. doi: 10.1007/s00248-015-0672-x

Salles, J. F., Le Roux, X., and Poly, F. (2012). Relating phylogenetic and functional diversity among denitrifiers and quantifying their capacity to predict community functioning. Front. Microbiol. 3:209. doi: 10.3389/fmicb.2012.00209

Salles, J. F., Pereira e Silva, M. D. C., Dini-Andreote, F., Dias, A. C. F., Guillaumaud, N., Poly, F., et al. (2017). Successional patterns of key genes and processes involved in the microbial nitrogen cycle in a salt marsh chronosequence. Biogeochemistry 132, 185-201. doi: 10.1007/s10533-0170296-y

Salles, J. F., Poly, F., Schmid, B., and Le Roux, X. (2009). Community niche predicts the functioning of denitrifying bacterial assemblages. Ecology 90, 3324-3332. doi: 10.1890/09-0188.1

Salles, J. F., van Elsas, J. D., and van Veen, J. A. (2006). Effect of agricultural management regime on Burkholderia community structure in soil. Microb. Ecol. 52, 267-279. doi: 10.1007/s00248-006-9048-6

Sasirekha, B., and Shivakumar, S. (2016). Siderophore production by Pseudomonas aeruginosa FP6, a biocontrol strain for Rhizoctonia solani and Colletotrichum gloeosporioides causing diseases in chilli. Agric. Nat. Resour. 50, 1-7. doi: 10.1016/j.anres.2016.02.003

Schnider-Keel, U., Seematter, A., Maurhofer, M., Blumer, C., Duffy, B., GigotBonnefoy, C., et al. (2000). Autoinduction of 2,4-diacetylphloroglucinol biosynthesis in the biocontrol agent Pseudomonas fluorescens CHA0 and repression by the bacterial metabolites salicylate and pyoluteorin. J. Bacteriol. 182, 1215-1225. doi: 10.1128/JB.182.5.1215-1225.2000

Schrama, M., Berg, M. P., and Olff, H. (2012). Ecosystem assembly rules: the interplay of green and brown webs during salt marsh succession. Ecology 93, 2353-2364. doi: 10.1890/11-1102.1

Schrama, M., Veen, G. F. C., Bakker, E. S. L., Ruifrok, J. L., Bakker, J. P., and Olff, H. (2013). An integrated perspective to explain nitrogen mineralization in grazed ecosystems. Perspect. Plant Ecol. Evol. Syst. 15, 32-44. doi: 10.1016/j.ppees.2012. 12.001

Schulz, B., and Boyle, C. (2006). "What are endophytes?," in Microbial Root Endophytes, eds B. Schulz, C. Boyle, and T. N. Sieber (Berlin: Springer-Verlag), 1-13. doi: 10.1007/3-540-33526-9

Seoighe, C. (2015). Algorithms and Framework for Nonnegative Matrix Factorization (NMF) CRAN. $R$ Package Version 0.20.6. Available at: http://cran.r-project.org/package=NMF

Sessitsch, A., Reiter, B., Pfeifer, U., and Wilhelm, E. (2002). Cultivationindependent population analysis of bacterial endophytes in three potato varieties based on eubacterial and Actinomycetes-specific PCR of 16S rRNA genes. FEMS Microbiol. Ecol. 39, 23-32. doi: 10.1111/j.1574-6941.2002. tb00903.x

Shakya, M., Gottel, N., Castro, H., Yang, Z. K., Gunter, L., Labbé, J., et al. (2013). A multifactor analysis of fungal and bacterial community structure in the root microbiome of mature Populus deltoides trees. PLOS ONE 8:e76382. doi: 10.1371/journal.pone.0076382

Sharma, A., and Johri, B. N. (2003). Growth promoting influence of siderophoreproducing Pseudomonas strains GRP3A and PRS9 in maize (Zea mays L.) under iron limiting conditions. Microbiol. Res. 158, 243-248. doi: 10.1078/0944-5013

Sidhu, G. S., Sharma, P., Chakrabarti, T., and Gupta, J. K. (1997). Strain improvement for the production of a thermostable? $\alpha$-amylase. Enzyme Microb. Technol. 21, 525-530. doi: 10.1016/S0141-0229(97)00055-0

Singh, B. K., Millard, P., Whiteley, A. S., and Murrell, J. C. (2004). Unravelling rhizosphere-microbial interactions: opportunities and limitations. Trends Microbiol. 12, 386-393. doi: 10.1016/j.tim.2004.06.008

Smalla, K., Sessitsch, A., and Hartmann, A. (2006). The rhizosphere: "soil compartment influenced by the root". FEMS Microbiol. Ecol. 56, 165. doi: 10.1111/j.1574-6941.2006.00148.x

Smalla, K., Wieland, G., Buchner, A., Zock, A., Parzy, J., Roskot, N., et al. (2001). Bulk and rhizosphere soil bacterial communities studied by denaturing gradient gel electrophoresis: plant-dependent enrichment and seasonal shifts revealed. Appl. Environ. Microbiol. 67, 4742-4751. doi: 10.1128/AEM.67.10.4742

Smeltzer, M. S., Hart, M. E., and Iandolo, J. J. (1992). Quantitative spectrophotometric assay for staphylococcal lipase. Appl. Environ. Microbiol. $58,2815-2819$.

Sunagawa, S., Coelho, L. P., Chaffron, S., Kultima, J. R., Labadie, K., Salazar, G., et al. (2015). Structure and function of the global ocean microbiome. Science 348:1261359. doi: 10.1126/science. 1261359

Tavakkoli, E., Fatehi, F., Coventry, S., Rengasamy, P., and McDonald, G. K. (2011). Additive effects of $\mathrm{Na}+$ and $\mathrm{Cl}$ - ions on barley growth under salinity stress. J. Exp. Bot. 62, 2189-2203. doi: 10.1093/jxb/erq422

Thompson, J. D., Gibson, T. J., Plewniak, F., Jeanmougin, F., and Higgins, D. G. (1997). The CLUSTAL_X windows interface: flexible strategies for multiple sequence alignment aided by quality analysis tools. Nucleic Acids Res. 25, 4876-4882. doi: 10.1093/nar/25.24.4876 
Timm, C. M., Campbell, A. G., Utturkar, S. M., Jun, S. R., Parales, R. E., Tan, W. A., et al. (2015). Metabolic functions of Pseudomonas fluorescens strains from Populus deltoides depend on rhizosphere or endosphere isolation compartment. Front. Microbiol. 6:1118. doi: 10.3389/fmicb.2015.01118

Turner, T. R., James, E. K., Poole, P. S., Gilbert, J., Meyer, F., Jansson, J., et al. (2013). The plant microbiome. Genome Biol. 14:209. doi: 10.1186/gb-2013-14-6-209

Uren, N. (2000). "Types, amount, and possible functions of compounds released into the rhizosphere by soil-grown plants," in The Rhizosphere: Biochemistry and Organic Substances At the Soil-Plant Interface, eds R. Pinton, Z. Varanini, and P. Nannipieri (New York, NY: Marcel Dekker), 1-24.

Venables, B., Hornik, K., and Maechler, M. (2016). polynom: A Collection of Functions to Implement a Class for Univariate Polynomial Manipulations. $R$ Package Version 1.3-9. Available at: https:/CRAN.R-project.org/package= polynom.

Versalovic, J., Schneider, M., de Bruijn, F. J., and Lupski, J. R. (1994). Genomic fingerprint of bacteria using repetitive sequence-based polymerase chain reaction. Methods Mol. Cell. Biol. 5, 25-40.

Vincent, Q. V. (2011). ggbiplot: A ggplot2 Based Biplot. R Package Version 0.55. Available at: http://github.com/vqv/ggbiplot

Walker, L., and del Moral, R. (2003). Primary Succession and Ecosystem Rehabilitation. Cambridge: Cambridge University Press. doi: 10.1017/ CBO9780511615078

Wang, M., Yang, P., and Salles, J. F. (2016). Distribution of root-associated bacterial communities along a salt-marsh primary succession. Front. Plant Sci. 6:1188. doi: $10.3389 /$ fpls. 2015.01188
Wickham, H. (2009). ggplot2: Elegant Graphics for Data Analysis. New York, NY: Springer-Verlag. doi: 10.1007/978-0-387-98141-3

Yan, Y., Kuramae, E. E., De Hollander, M., Klinkhamer, P. G., and van Veen, J. A. (2016). Functional traits dominate the diversity-related selection of bacterial communities in the rhizosphere. ISME J. 11, 56-66. doi: 10.1038/ismej.2016.108

Yang, J., Kloepper, J. W., and Ryu, C. M. (2009). Rhizosphere bacteria help plants tolerate abiotic stress. Trends Plant Sci. 14, 1-4. doi: 10.1016/j.tplants.2008. 10.004

Yilmaz, P., Parfrey, L. W., Yarza, P., Gerken, J., Pruesse, E., Quast, C., et al. (2014). The SILVA and "all-species Living Tree Project (LTP)" taxonomic frameworks. Nucleic Acids Res. 42, 643-648. doi: 10.1093/nar/gkt1209

Zhang, H., Irving, L. J., McGill, C., Matthew, C., Zhou, D., and Kemp, P. (2010). The effects of salinity and osmotic stress on barley germination rate: sodium as an osmotic regulator. Ann. Bot. 106, 1027-1035. doi: 10.1093/aob/mcq204

Conflict of Interest Statement: The authors declare that the research was conducted in the absence of any commercial or financial relationships that could be construed as a potential conflict of interest.

Copyright (c) 2017 Wang, Li, Liu, Jousset and Salles. This is an open-access article distributed under the terms of the Creative Commons Attribution License (CC BY). The use, distribution or reproduction in other forums is permitted, provided the original author(s) or licensor are credited and that the original publication in this journal is cited, in accordance with accepted academic practice. No use, distribution or reproduction is permitted which does not comply with these terms. 